NBER WORKING PAPER SERIES

\title{
THE MEDIUM RUN EFFECTS OF EDUCATIONAL EXPANSION: EVIDENCE FROM A LARGE SCHOOL CONSTRUCTION PROGRAM IN INDONESIA
}

\author{
Esther Duflo \\ Working Paper 8710 \\ http://www.nber.org/papers/w8710 \\ NATIONAL BUREAU OF ECONOMIC RESEARCH \\ 1050 Massachusetts Avenue \\ Cambridge, MA 02138 \\ January 2002
}

I thank participants at the conference "New Research on Education in Developing Countries" at the Center for Research on Economic Development and Policy Reform of Stanford University for comments, and particular to Hanan Jacoby for his discussion of the paper. I also thank two referees and the editor for very useful comments. I thank Lucia Breierova for excellent research assistance, Daron Acemoglu, Joshua Angrist, Abhijit Banerjee, Robert Barro, Ricardo Caballero, David Card, Michael Kremer, Emmanuel Saez, and Jaume Ventura for very helpful discussions, and Guido Lorenzoni for his insights about transitional dynamics. The views expressed herein are those of the author and not necessarily those of the National Bureau of Economic Research.

(C) 2002 by Esther Duflo. All rights reserved. Short sections of text, not to exceed two paragraphs, may be quoted without explicit permission provided that full credit, including (C) notice, is given to the source. 
The Medium Run Effects of Educational Expansion: Evidence from a

Large School Construction Program in Indonesia

Esther Duflo

NBER Working Paper No. 8710

January 2002

JEL No. O1, O4, I2

\begin{abstract}
$\underline{\text { ABSTRACT }}$
This paper studies the medium run consequences of an increase in the rate of accumulation of human capital in a developing country. From 1974 to 1978, the Indonesian government built over 61,000 primary schools. The school construction program led to an increase in education among individuals who were young enough to attend primary school after 1974, but not among the older cohorts. 2SLS estimates suggest that an increase of 10 percentage points in the proportion of primary school graduates in the labor force reduced the wages of the older cohorts by $3.8 \%$ to $10 \%$ and increased their formal labor force participation by $4 \%$ to $7 \%$. I propose a two-sector model as a framework to interpret these findings. The results suggest that physical capital did not adjust to the faster increase in human capital.
\end{abstract}

Esther Duflo

Department of Economics

Massachusetts Institute of Technology

E52-252G

50 Memorial Drive

Cambridge, MA 02142

and NBER

eduflo@mit.edu 


\section{Introduction}

Evaluations of social programs in developing economies tend to focus on the short run and "partial equilibrium" effects of these programs, and do not try to assess their macroeconomic consequences. Empirical studies of the determinants of economic growth form a largely independent subfield that uses predominantly cross-country data sets. This division is unfortunate. While aggregate cross-country data is readily available and simple to use, it can lead to misleading conclusions, either because aggregate data is of poor quality (Krueger and Lindahl (1999) Atkinson and Brandolini (1999)) or because regressions are mis-specified (Banerjee and Duflo (2000)). Conversely, policy recommendations based on "partial equilibrium" analysis can be misleading, if the "general equilibrium" effects undo the direct effects of the policy (Heckman, Lochner and Taber (1998)).

Moreover, the aggregate response to large programs is of independent interest, and can be a fruitful source of identification of macroeconomic relationships. In particular, large programs are well identified shocks. Studying the economy's aggregate response to these shocks is an occasion to understand the process of adjustment. The adjustment of an economy to shocks is the objective of macroeconomic studies of the "medium run" (Solow (2000)). In particular, macroeconomists and labor economists have long been interested in labor supply shocks, such as changes in cohort sizes (Welch (1979)), the level of education of the labor force (Katz and Murphy (1992)), changes in level of education by cohorts (Card and Lemieux (2001)), or adverse labor supply shocks in Europe (Blanchard (1997)). The speed and efficiency of adjustment are important dimensions of the effects of a range of economic policies. Trade policy analysis, for example, often assumes immediate adjustment of the production decisions, which could be extremely misleading. The long term effects of economic crises, as well as the appropriate policy response, are closely linked to whether they lead to efficient or inefficient restructuring, which is linked to the ability of the economy to allocate factors efficiently (Caballero and Hammour (2000)). Thus, studying the aggregate consequences of large programs can inform economic policy beyond the specific program considered. 
Most studies of the medium run consequences of labor supply shocks focus on the U.S. or on Europe. Yet, the response of the economy to a shock is closely related to its market institutions. ${ }^{1}$ In developing countries, because market institutions (credit market, contractual enforcement, labor market regulations) are less effective, one might expect the adjustment process to be particularly sluggish. Caballero and Hammour (2000) argue that institutional failures, because they lead to mis-allocation of resources and inefficiently slow restructuring, is at the root of underdevelopment. The evidence on medium term adjustment in developing countries is, however, extremely limited.

This paper studies the effects of a dramatic policy change that differentially affected different cohorts and different regions of Indonesia on the allocation of the labor force across sectors and on wages. In 1973, the Indonesian government launched a major school construction program, the Sekolah Dasar INPRES program. Between 1973-74 and 1978-79, more than 61,000 primary schools were built. In earlier work (Duflo (2000)), I showed that the program had an impact on the education and wages of the cohorts exposed to it. This paper studies the behavior of wage rates and formal labor force participation of those who were not directly exposed to the program, from 1986, 12 years after the school construction program was initiated (and when the first generation exposed to the program just entered the labor force) to 1999. This is therefore a study of the "medium" run aggregate effects of the program. Until 1997, this was a period of rapid growth for the Indonesian economy: between 1986 and 1999, the economy grew by over $50 \%$, and the share of the labor force in manufacturing doubled (from $6 \%$ to $13 \%$ ). Industrialization occurred throughout Java, and in concentrated pockets in the other Islands Miguel, Gertler and Levine (2001).

I first show that the program led to faster increases in the fraction of primary school graduates in the regions where it was more important, between 1986 and 1999. This increase is strikingly similar to that which would have been predicted in the absence of any migration. I then proceed

\footnotetext{
${ }^{1}$ See Blanchard and Wolfers (1999) for a comparison of the reaction to the labor supply shocks in the 1970s across European countries with different labor market institutions.
} 
to look at the effect of the program on the wages and the formal labor force participation of the cohorts that did not directly benefit from it, because they were already out of school when the program started. This allows us to look at the impact of the increase in education on factor returns, for a population whose skill level is not affected. It turns out that wages increased less rapidly from year to year in regions that received more schools. This holds even after controlling for the factors that determined the initial allocation, and may have caused different growth trajectories across these regions.

Using interactions between the survey year and the number of INPRES schools per 1,000 children as instruments for the fraction of educated workers in the region therefore suggests a negative effect of the proportion of primary school graduates on individual wages, keeping the individuals' own skill level constant. On the other hand, an increase in the fraction of educated workers seems to cause an increase in the participation of both educated and uneducated workers in the formal labor market. The negative impact of average education on individual wages does not seem to be explained by selection bias caused either by selective migration or by selective entry into the formal labor market.

I propose a simple two sector model as a framework to interpret these effects and their magnitude. Individuals can work either in the informal or in the formal sector. In the informal sector, they are self employed and labor (skilled and unskilled) is combined with land, a fixed factor. In the formal sector, labor (skilled an unskilled) is combined with capital, and individuals earn a wage. The production function in the formal sector exhibits constant returns to physical and human capital combined. The fact that the increase in the share of educated workers led to a movement of workers from the informal to the formal sector indicates that the elasticity of substitution between labor and land in the informal sector is smaller than the elasticity of substitution between labor and capital in the formal sector. The elasticity of the supply of capital with respect to the share of educated labor determines the predicted effect of the program on wages in the model. I compare two polar versions of the model. The benchmark version assumes costless adjustment of the capital stock. In this case, in the period we study (1986 to 1999, 12 to 
25 years after the program was initiated), physical and human capital should grow at the same rate and there should be no relative fall in wages in regions where human capital grows faster. This holds in a closed economy model as well as in an open economy model where capital is accumulated nationally and efficiently allocated across regions. The second version, in contrast, compares the empirical estimates I obtain to the parameters predicted by the model in the absence of any adjustment of capital to the increase in education. These empirical estimates are close to what this version of the model would predict. This suggests that physical capital did not adjust to the regional differences in the rate of accumulation of human capital induced by the program.

The remainder of this paper is organized as follows. In section 2, I describe the INPRES program and its effects on average education. In section 3 , I discuss the identification of the effects of average education on individual wages and derive the empirical specifications. Section 4 presents the results. Section 5 presents the model that organizes and explains the findings, and compares the estimates to what the two polar versions (costless adjustment of capital or no adjustment of capital) of the model would predict.

\section{The program and its effects on average education}

\subsection{The Sekolah Dasar INPRES program}

In 1974, the Indonesian government initiated a large primary school construction program, the Sekolah Dasar INPRES program. Between 1974 and 1978, 61,807 new buildings were constructed, doubling the number of available schools per capita. More schools were put in regions where initial enrollment rates were low, which caused important regional variations in the intensity of the program. Using a large household survey conducted in 1995 (the SUPAS 1995) linked to data on the number of schools constructed in each individual's region of birth, Duflo (2001) showed that the growth in education between cohorts unexposed to the program and cohorts exposed to the program was faster in regions that received more INPRES schools. This differ- 
ence can be attributed to the program with a reasonable level of confidence, because no similar pattern is present if we compare cohorts that were not exposed to the program. In addition, the program affected mostly primary school completion, whereas omitted factors would have affected other levels of schooling as well. This pattern is summarized in figure 1, reproduced from Duflo (2001). Each point on the solid line summarizes the effect one more school built per 1,000 children had on the average education of children born in each cohort. ${ }^{2}$ Children in Indonesia normally go to primary school until age 12 (although delay at school entry and repetition are not uncommon), therefore one would expect the effect of the program to be 0 for children who reached 12 before 1974, when the first schools were built, and to be progressively increasing. This is exactly what the picture shows.

If migration flows were either small or not affected by the program, one would expect to see a similar pattern when comparing the evolution of average education among adults over the years in the different regions. As the generations exposed to the program enter the labor market, one should see the average education (and in particular the fraction of primary school graduates) increase faster in the regions that received more schools.

\subsection{Data and empirical specification}

The data for this paper comes primarily from the annual Indonesian Labor Force Survey (SAKERNAS), from 1986 to 1999. These surveys are repeated cross sections, of approximately 60,000 households. The surveys contain information on province and district of residence (but not of birth), education level achieved, labor force participation, type of employment, number of hours worked in the last week, and wages for individuals who work for a wage in their primary occupation. Using this data, I construct the average hourly wage as weekly wage divided by hours worked on this occupation. An individual is considered as part of the formal sector if he works for a wage in his primary occupation. The survey questions and definitions are homogenous

\footnotetext{
${ }^{2}$ These are the coefficients obtained by regressing years of education on the the interactions between the number of schools built per capita in the individual's region of birth and year of birth dummies, after controlling for year and region of birth fixed effects.
} 
between 1986 and 1999. I restrict the sample to males aged 20 to 60, and I exclude Jakarta. Descriptive statistics are presented in table 1. The fraction of individuals born after 1962, and therefore theoretically exposed to the program, in the age groups 20-40 and 20-60, increases progressively over the years. I consider the proportion of primary school graduates in each region in each year. There is a total of 3,826 district-year cells, with an average of 287 individual observations in each cell in the full sample. ${ }^{3}$ All regressions are performed on this aggregate data set, and each cell is weighted by the number of observations used to construct it.

Consider comparing two regions in 1986 and 1999, one of which received a large number of INPRES schools per capita, while the other one received a small number of schools. The fraction of people who were young enough to be exposed to the INPRES program is bigger in 1999 than in 1986. We know that the gains in years of education of these younger cohorts, relative to the older ones, were bigger in the regions that received more schools. If the effect of the program was not undone by migration, one would expect the average education (in particular, the proportion of primary school graduates) to have grown faster between 1986 and 1999 in the region that received more schools. This suggests comparing the difference in educational attainments between 1999 and 1986 in these two regions. More generally, this suggests that, if one runs a regression of the difference between average educational attainment in 1999 and 1986 on the number of schools per capita built in each region, one should see a positive coefficient. Clearly, this reasoning also applies to any year-to-year difference.

In summary, this suggests the following specification:

$$
\overline{S_{j t}}=\mu_{t}+\nu_{j}+\sum_{l=1987}^{1999}\left(\lambda_{l} * P_{j}\right) \gamma_{1 l}+\sum_{l=1987}^{1999}\left(\lambda_{l} * C_{j}\right) \delta_{1 l}+\epsilon_{j t}
$$

where $\overline{S_{j t}}$ is the proportion of primary school graduates among adults in year $t$ in region $j$, $\mu_{t}$ is a survey year fixed effect and $\nu_{j}$ is a region fixed effect, $P_{j}$ is the number of INPRES schools built between 1974 and 1978 in district $j$, and $\lambda_{l}$ is a survey year dummy $\left(\lambda_{l}=1\right.$ if $t=l$, and 0 otherwise). $C_{j}$ is a vector of initial conditions that are introduced as control

\footnotetext{
${ }^{3}$ There are on average 185 observations per cell of individuals born before 1962 , including 61 with wage data.
} 
variables. In particular, it may be important to control for the enrollment rate in 1971, since it was a determinant of the placement of the program. Note that the first-order effect of a higher enrollment rate in 1971 is a difference in level of education, which should affect all cohorts, and all survey years identically, and therefore be absorbed by the region fixed effect. Only a change in the rates at which children attend school in a region will lead to a change in the rate at which average education increases from year to year. Therefore, controlling for the enrollment rate in 1971, interacted with year dummies, is important only to the extent that we think changes in enrollment rates are correlated with levels. I also control for the number of children in 1971.

\section{$2.3 \quad$ Results}

Since the generations exposed to the program have already started entering the sample in 1986 , one would expect all the coefficients of the interactions between program intensity and survey year dummies to be positive and increasing. Columns 1, 2, 4 and 5 in table 2 show these coefficients for the specification that includes enrollment rates as a control, for adults aged 20 to 40 and for adults aged 20 to 60 , in the whole sample and in a sample that excludes urban districts. ${ }^{4}$ The fraction of "young" (or exposed) people among individuals aged 20 to 40 increases faster than among those aged 20 to 60 , and one would expect the coefficients to be larger and more significant in the former group. The group of individuals aged 20 to 60 , however, corresponds better to "the labor market", and will therefore be important in the second stage of this analysis. The coefficients are increasing for both groups, they are jointly significant, and, as expected, they are larger in the group aged 20 to 40. They become individually significant from 1991 in the 20-40 group and from 1996 in the 20-60 group.

This pattern could have been caused by other factors than the increase in education due to INPRES, for example by migration of educated workers into districts that received more INPRES schools. If we had data from earlier years, it would be possible to use "pre-program" data to test the identification assumption that the increase in education levels over time would not

\footnotetext{
${ }^{4}$ The specification without enrollment rates as a control is very similar, and is therefore omitted.
} 
have been systematically different in regions where a different number of schools was built, even in the absence of the program. No comparable survey was realized before 1986. If the pattern was due to something other than the effect of the program on education, however, one would see a faster (or slower) increase in the education over the years, even in the subsample of those who were not exposed to the program (individuals born in 1962 or before). To check this, I estimated a specification similar to equation 1, with the fraction of primary school graduates among individuals born in 1962 or before as the dependent variable. The coefficients are presented in columns 3 and 6 in table 2. Figure 2 gives a graphical summary of these estimates: It shows the coefficients (and their confidence intervals) for the entire group aged 20 to 40, and for the group of individuals born before 1962. There is no systematic increase among the group born before 1962. The coefficients in the two equations are significantly different from each other. This indicates that the increase in average education is likely due to the program, rather than to other factors.

\subsection{Does migration undo the effect of local infrastructure development?}

Although migration flows were not very important in Indonesia over the period, they are far from negligible. In 1995, if one excludes Jakarta, $12 \%$ of individuals in the SUPAS sample did not live in their province of birth, and $24 \%$ did not live in their district of birth ( $17 \%$ if one excludes the urban districts). Among individual born in 1962, 13\% did not live in their province of birth, and $25 \%$ did not live in their district of birth. It is therefore interesting to study whether out migration of educated workers dampened the effect of the program on average education in the labor market.

The results in the previous section already suggest a partial answer to this question. The program affected the average education of adults, which indicates that its effects were not totally undone by migration. We can, however, make this result more precise by comparing the effect the program should have had, in the absence of any off-setting effect of migration, with the effect it had in reality. The results from this exercise are important in the context of an increasing focus 
on decentralization, notably in Indonesia. If local governments consider that their communities are not getting any benefits from investment in education because educated people migrate (with their human capital), decentralization of school finance may lead the public financing of education to decline. ${ }^{5}$

To get at this question, I first estimated the effect of the number of INPRES schools constructed per capita in an individual's district of birth on the probability that an individual completed primary school, for each cohort. To this end, I used the SUPAS 1995 data. The SUPAS (Intercensal survey of Indonesia) is a sample of over 200,000 household. It is representative at the district level. It is conducted every 10 years by the Central Bureau of Statistics of Indonesia. The survey collects the same information as the SAKERNAS (which it replaces in 1995), as well as more information about household members, in particular their province and district of birth. The sample for this analysis is men born between 1950 and 1972 (there are 152,989 individuals in the sample).

Using this data, I regressed a dummy indicating whether an individual completed primary school on a set of district of birth fixed effects, cohort of birth fixed effects, and interactions between the number of schools constructed in one's district of birth and year of birth dummies. The equation estimated is identical to equation (11) in Duflo (2001), except that it used the primary school completion as the dependent variable. Denote the estimated effect of the program on the cohort born in year $k$ as $\hat{\pi}_{k}$. I used the 1995 data to compute the proportion of primary school graduates among those aged 20 to 40 in each year (from 1986 to 1999) born in each district before 1962. Denote this average by $\widetilde{S_{o j}}$. For each survey year $t$ and year of birth $k$, denote by $\phi_{k t}$ the share of those aged 20 to 40 who were born in year $k{ }^{6}$ We can then compute the proportion of primary school graduates predicted by the program in each district and each year as:

\footnotetext{
${ }^{5}$ Bound, Kzedi and Turner (2000) ask the same question for college education in the U.S.

${ }^{6}$ All the individuals who are born in 1962 or before are in the same cohort $k$.
} 


$$
\widetilde{S_{j t}}=\widetilde{S_{o j}}+P_{j}\left(\sum_{k=1962}^{t-20} \hat{\pi_{k}} \phi_{k t}\right)
$$

Note that this predicted value does not contain any information specific both to the district and the year considered. There is therefore no source of mechanical relationship between $\widetilde{S_{j t}}$ and $\overline{S_{j t}}$. The first observation is that $\widetilde{S_{j t}}$ and $\overline{S_{j t}}$ are strongly correlated. The regression of the actual share of primary school graduates on the predicted share leads to a coefficient of 0.84 , with a t-statistic of 77). This, however, is not very informative, because a large part of this correlation is driven by those born before 1962, and would therefore still exist even if all the educated young had migrated out of the high program districts. The following experiment is more informative. I run the same specification as in equation 1 , but I use as the dependent variable the predicted education, $\widetilde{S_{j t}}$. These coefficients indicate how the average education of adults would have been affected in each region in the absence of any offsetting effect of migration. The coefficients $\gamma_{1 l}$ obtained in this specification are plotted in figure 3 , along with the coefficients obtained when estimating equation 1 with the actual average as the dependent variable. The two sets of coefficients are surprisingly close to each other. In particular, there is no evidence that the predicted effect is bigger than the actual effect.

\section{Identifying the effect of a change in average education}

\subsection{Conceptual framework}

Consider an economy with two sectors. Assume that there are only two types of workers, educated (with a primary education or more) and uneducated (no primary education). Assume that the formal sector employs educated labor, uneducated labor, and capital, and the informal sector employs educated and uneducated labor and land. ${ }^{7}$ Individuals are self-employed in the informal sector, and receive a wage in the formal sector. Consistent with Harris and Todaro

\footnotetext{
${ }^{7}$ We could allow land and capital to present in both sectors, but we would have to model migration of capital and land between sector, for which we have little data.
} 
(1970) and other dual economy models of development, we view the potential of growth of the informal sector limited while the economic growth happens as the formal sector expands. This is reflected in the assumption that land is a fixed factor. The share of the labor force employed in the formal sector and their wages are the two variables of interest.

The production functions in the formal and informal sectors are given by $f\left(A_{F}, E_{F}, U_{F}, K\right)$ and $g\left(A_{I}, E_{I}, U_{I}, T\right)$ respectively, where $K$ and $T$ are the stock of capital and land respectively, $E_{F}$ and $U_{F}$ denote educated and uneducated labor employed in the formal sector, respectively, $E_{I}$ and $U_{I}$ denote educated and uneducated labor employed in the informal sector, and $A_{F}$ and $A_{I}$ are "productivity" parameters. We will treat the total population as a constant (nothing is affected by allowing steady population growth). The wages, as well as the fraction of educated and uneducated workers who are working in each sector, are determined jointly in equilibrium as a function of the number of educated and uneducated workers (in the economy as a whole), the stock of capital, the stock of land, and the parameters $A_{F}$ and $A_{E}$.

Normalizing the entire labor force to 1 , and denoting $S$ the share of educated workers, we can therefore write the wage and formal employment functions as: ${ }^{8} \ln \left(w_{E}\right)=\phi_{E}\left(A_{F}, A_{I}, K(S), S, T\right)$, $\ln \left(w_{u}\right)=\phi_{U}\left(A_{F}, A_{I}, K(S), S, T\right), E_{F}=\psi_{E}\left(A_{F}, A_{I}, K(S), S, T\right)$, and $U_{F}=\psi_{U}\left(A_{F}, A_{I}, K(S), S, T\right)$.

$K$ is explicitly written as a function of $S$, to reflect the fact that a change in the proportion of educated workers has a direct effect (the effect of the share of educated workers on the wage), and an indirect effect due to the accumulation of physical capital in response to this increase. The elasticity of physical capital with respect to the share of educated labor is an empirical question: In the long run, one might expect the physical capital to adjust to a change in the fraction of educated workers, while in the very short run, adjustment will be much more limited. In the "medium run", the speed of adjustment of the capital stock will depend on the flexibility of the production function and the availability of finance for the installation of new capital.

Consider a Taylor expansion of the wage function around $S=0$.

$$
\phi_{s}\left(A_{F t}, A_{I t}, K_{t}\left(S_{t}\right), S_{t}, T_{t}\right) \simeq \phi_{s}\left(A_{F t}, A_{I t}, K_{t}\left(S_{t}=0\right), S_{t}=0, T_{t}\right)+S_{t} \frac{\partial \phi_{s}}{\partial S}+S_{t} \frac{\partial K}{\partial S} \frac{\partial \phi_{s}}{\partial K} .
$$

\footnotetext{
${ }^{8}$ Writing the wage function directly in logarithm, for convenience.
} 
Denoting $K_{t}\left(S_{t}=0\right)$ by $\tilde{K}_{t}$, this can be rewritten:

$$
\ln \left(w_{s t}\right)=\left(\frac{\partial \phi_{s}}{\partial S}+\frac{\partial K}{\partial S} \frac{\partial \phi_{s}}{\partial K}\right) S_{t}+\phi_{1 s}\left(A_{F t}, A_{I t}, \widetilde{K}_{t}, T_{t}\right)
$$

We, therefore, seek to estimate the coefficient $\alpha_{s}$ in the expression:

$$
\ln \left(w_{s t}\right) \simeq \alpha_{s} S_{t}+\phi_{1 s}\left(A_{F t}, A_{I t}, \widetilde{K}_{t}, T_{t}\right)
$$

In this expression, $\alpha_{s}$ reflects the direct effect of $S$ on the wage, as well as any indirect effect due to the response of the stock of physical capital to the stock of human capital. The sign of $\alpha_{s}$ is not determined a priori. If capital adjusts slowly, or if there are diminishing returns to capital and labor combined, $\alpha_{s}$ will tend to be negative, reflecting the fact that the increase in the share of educated workers increase the quantity of labor (measured in efficiency units). If capital adjusts rapidly and there is no fixed factor, $\alpha_{s}$ would be zero and even positive in the presence of an external effect of education (as in Lucas (1988)) or if an increase in the share of educated workers led to a more than offsetting increase in the stock of physical capital (Acemoglu (1996)).

Consider running a regression of the wage of the uneducated workers on the share of educated workers in the economy, without controlling for the stock of capital. Clearly, if there is any correlation between the level of capital (and the productivity of the formal and informal sector) and the share of educated people, this relationship will be biased. Since this is likely to be the case, coefficients obtained in such a regression cannot really be interpreted.

Since there are many districts and years, we could instead compare wage growth across districts. Using equation 3 , the growth of the log wage between two periods is given by:

$$
\ln \left(w_{s t}\right)-\ln \left(w_{s t-1}\right) \simeq \alpha_{s}\left(S_{t}-S_{t-1}\right)+\phi_{1 s}\left(A_{F t}, A_{I t}, \widetilde{K}_{t}, T_{t}\right)-\phi_{1 s}\left(A_{F t-1}, A_{I t-1}, \widetilde{K}_{t-1}, T_{t-1}\right)
$$

If we estimate this relationship using an OLS regression, and we omit the term $\phi_{1 s}\left(A_{F t}, A_{I t}, \widetilde{K_{t}}, T_{t}\right)-$ $\phi_{1 s}\left(A_{F t-1}, A_{I t-1}, \widetilde{K_{t-1}}, T_{t-1}\right)$, the coefficient $\alpha_{s}$ will be biased if there is a correlation between physical capital accumulation and human capital accumulation. In almost any model of human and physical capital accumulation based upon individual maximization, the increase in the share 
of educated workers and the rate of physical capital accumulation will be related: in particular, both are determined by the discount rate in the economy. In order to estimate the parameter $\alpha_{s}$ consistently, we therefore need an instrument, correlated with the increase in the share of educated workers, but not with the evolution in the other factors in the economy. ${ }^{9}$

A potential instrument for $\left(S_{t}-S_{t-1}\right)$ in our setting is the number of primary schools constructed by the INPRES program. To understand how the instrument works and its limitations, suppose first that the government allocated the schools randomly. Each school reduces the effective cost of schooling, and therefore increases the enrollment rate among all the future young generations (but not that of the older generations). The increase in the number of schools combined with the fact that the young generations progressively enter the labor market starting in the late 1980's changes the rate of growth of $S$ over time. The modification in the rate of growth is a function of the number of schools built, which suggests that if the schools had been allocated randomly, the number of INPRES schools would form an ideal instrument.

In practice, however, the government allocated more schools in regions where enrollment rates at the primary school level were lower. The evidence presented in this paper and in Duflo (2001) suggests that the rate of growth of human capital was not systematically correlated with the program before it was initiated. Nevertheless, the level of the program will not be a valid instrument for $\left(S_{t}-S_{t-1}\right)$ if it is correlated with the rate of capital accumulation. This would happen if educational attainments in 1971 were correlated with capital accumulation between 1986 and 1999. Regions with a lower level of educational attainment tend to be poorer, and could therefore have been growing faster, if there had been a tendency for Indonesian regions to converge. In practice, Indonesian provinces exhibited very little convergence in gross provincial product per capita until 1996 (Hill (1996)). Nevertheless, to control for possible convergence, we will control for enrollment rate in 1971. We will also present the results in the rural sample

\footnotetext{
${ }^{9}$ For example, Moretti (1999), proposed to instrument for $\left(S_{t}-S_{t-1}\right)$ with the share of young people in the base year, on the ground that education will grow faster in regions which have more young people. The problem remains, however, that the share of young people in the base year is very likely to influence physical capital accumulation as well.
} 
separately, and omit the years 1998 and 1999 to allow for the fact that the Indonesian crisis hit wages in richer regions, and in particular cities, much more than in poorer regions and in rural areas (Frankenberg, Thomas and Beegle (1999)), causing some convergence of wage rates between regions.

\subsection{Empirical specifications}

The wage of individual $i$ observed in district $j$ in year $t$ is given by:

$$
\ln \left(w_{i j t}\right)=S_{i}\left(\ln \left(w_{E j t}\right)-\ln \left(w_{U j t}\right)\right)+\ln \left(w_{U j t}\right)+v_{i j t}
$$

where $S_{i}$ is a dummy indicating whether the individual has graduated from primary school. The error term $v_{i j t}$ reflects all the other factors that determine wage, besides individual and average education.

Substituting the expression for $\ln \left(w_{E j t}\right)$ from equation 3 and including all the variables which we do not measure in the error term, we obtain a relationship between individual wage, individual education level, and regional human capital in the district at date $t$.

$$
\ln \left(w_{i j t}\right)=S_{i} b_{j t}+\alpha_{U} S_{j t}+\epsilon_{j t}+\mu_{t}+\nu_{j}+v_{i j t},
$$

where $b_{j t}=\left(\ln \left(w_{E j t}\right)-\ln \left(w_{U j t}\right)\right)($ the skill premium $)$, and $\left.\mu_{t}+\nu_{j}+\epsilon_{j t}=\phi_{1 U}\left(A_{F j t}, A_{I j t}, \widetilde{K}_{j t}, T_{j}\right)\right)$

As we have seen, estimating this equation by OLS (treating $b_{j t}$ as a random coefficient) could be very misleading, because of the correlation between $\epsilon_{j t}, \mu_{t}$ or $\nu_{j}$ and $S_{j t}$. In addition, Acemoglu and Angrist (1999) show that, even if there is no omitted district level variable, the OLS estimate of $\alpha_{U}$ will be a biased estimate of the effect of $S_{j t}$ on $\ln \left(w_{i j t}\right)$ if the estimate of $b_{j t}$ is biased for any reason (such as measurement error in the education variable, or the endogeneity of education). They propose to instrument for both $S_{i}$ and $S_{j t}$. Alternatively, one could instrument $S_{j t}$ with a variable that does not affect $S_{i}$, the individual education, which is the approach we take here. 
The nature of the INPRES program suggests the following instrumental variable strategy. All individuals who were born in 1962 or before were not affected by the program (we have verified in the previous section that the average education in this group did not grow faster from year to year in the districts that received more INPRES schools). On the other hand, the program affected the average education by affecting the education of those born after 1962. Therefore, the intensity of the INPRES program is a potential instrument for the average education which does not affect individual education, if we restrict the sample to those born before 1962 .

To derive the empirical specification, take the average of equation 6 for all individuals born before 1962:

$$
\overline{\ln \left(w_{i j t}\right)}=\overline{S_{j t o}} b_{j t}+S_{j t} \alpha_{U}+\mu_{t}+\mu_{j}+\overline{v_{i j t}}
$$

where $\overline{S_{j t o}}$ is the proportion of primary school graduates among the old (born before 1962) in year $t$ in district $j$. If we take the first difference of this equation and rearrange the terms, we obtain:

$\overline{\ln \left(w_{i j t}\right)}-\overline{\ln \left(w_{i j t-1}\right)}=\left(\overline{S_{j t o}}-\overline{S_{j t-1 o}}\right) b_{j t-1}+\overline{S_{j t-1 o}}\left(b_{j t}-b_{j t-1}\right)+\left(S_{j t}-S_{j t-1}\right) \alpha_{U}+\mu_{t}+\nu_{j}+\epsilon_{j t}+\overline{v_{i j t}}$

The evolution of the skill premium $\left(b_{j t}-b_{j t-1}\right)$ is itself a function of the evolution in the number of educated workers in the region, so that the effect of the evolution of primary school graduates on the average wages of the individual born before 1962 is finally given by the expression:

$$
\overline{\ln \left(w_{i j t}\right)}-\overline{\ln \left(w_{i j t-1}\right)}=\left(S_{j t}-S_{j t-1}\right) \alpha+\mu_{t}^{\prime}+\nu_{j}^{\prime}+\epsilon_{j t}^{\prime}+\overline{v_{i j t}}
$$

Subject to the caveats discussed in the previous sub-section, we can use the number of INPRES schools $\left(P_{j}\right)$ as an instrument for $S_{j t}-S_{j t-1}$ in equation 8, possibly after controlling for variables such as the enrollment rate and the wage in 1986 (a vector $C_{j}$ ). We have verified that $P_{j}$ is uncorrelated with $\left(\overline{S_{j t o}}-\overline{S_{j t-1 o}}\right)$, which is now included in the error term. 
A joint test of the validity of the strategy and the seriousness of the problem suggested by Acemoglu and Angrist (1999) is to use as dependent variable the average of the residual of a regression of individual wages on individual education. If this equation is correctly specified, it should lead to the similar, but more precise estimate (since $\left(\overline{S_{j t o}}-\overline{S_{j t-1 o}}\right)$ will not be part of the error term any more).

Thus the reduced form with two years of data would be written:

$$
\overline{\ln \left(w_{j t}\right)}-\overline{\ln \left(w_{j t-1}\right)}=\mu_{t}+\gamma_{2} P_{j}+\delta_{2} C_{j}+\xi_{j t}
$$

This equation can be generalized to incorporate all available years, leading to a reduced form equation similar to equation 1 :

$$
\overline{\ln w_{j t}}=\mu_{t}+\nu_{j}+\sum_{l=1987}^{1999}\left(\lambda_{l} * P_{j}\right) \gamma_{2 l}+\sum_{l=1987}^{1999}\left(\lambda_{l} * C_{j}\right) \delta_{2 l}+\epsilon_{j t},
$$

where $\mu_{t}$ and $\gamma_{j}$ are year and district fixed effects, respectively.

Equations 1 and 9 form respectively the first stage and the reduced form of an instrumental variables strategy to estimate equation 7 .

The same reasoning applies to formal labor force participation, and the same specification can be estimated with formal labor force participation instead of wages. Finally we can also estimate equations similar to equation 7 , using the average skill premium as dependent variable. The variables we consider here (wages, education, skill premium, formal labor force participation) are likely to be auto-correlated over time. Bertrand and Mullainathan (2001) show that it can result in large understatement of the standard errors in these types of setting. I thus correct standard errors in all equations using a generalization of the White variance formula which allows for a flexible auto-correlation process within any states.

Since the sample of individuals not affected by the program that we include in the analysis is different every year, this specification may suffer from sample selection. First, the program may have induced selective migration by the old people, potentially correlated with their productivity, and therefore with their wages. Second, we will show that the program affected the proportion 
of old people who work for a wage: it also opens some room for selection bias, since it is possible that workers with the lowest productivity switched to the wage sector. Section 4.5 will present additional evidence (using two other data sets) on whether these two possibilities for sample selection affected the results.

\section{Results}

Summary statistics for the sample of people born before 1962, and aged 60 or less in the survey year, are presented in table 3 . The proportion of primary school graduates among them increased from $59 \%$ to $74 \%$ between 1986 and 1989 (this reflects the fact that individuals present in the sample belong to later cohorts in later years). We use as an indicator of formal employment the fact that someone receives a wage. This fraction is a little over $30 \%$. The average wage, in real terms, increased by about 50\% between 1986 and 1997, and declined by $22 \%$ between 1997 and 1999.

\subsection{Reduced form results}

The reduced form results (the estimates of the coefficients $\gamma_{2 l}$ in equation 9) are presented in table 4 and in figures $4 \mathrm{~A}$ and $4 \mathrm{~B}$. These two figures summarize the reduced form effects on wages and on formal employment. Although none of these coefficients is individually significantly different from zero, the reduced form coefficients in the wage equation are declining (in contrast to the coefficients of average education, which are increasing). The reduced form coefficients on the probability of working for a wage are increasing. In the sample that includes both urban and rural areas, the coefficients increase from 1997 to 1999, which probably reflects the differential impact of the crisis. In the rural sample, they are monotonically declining. 


\subsection{The effects of average education on wage rates}

The main sample for the analysis is all the individuals aged 20 to 60 who were born before $1962 .{ }^{10}$ I will consider two independent variables. First, the fraction of primary school graduates in the sample aged 20 to 60 (a reasonable approximation of the average education in the labor market); second, the fraction of primary school graduates among the 20-40 sample. The INPRES program directly affected the latter (since the older affected people were 37 in 1999). The former was affected as a consequence: Focusing on the 20-40 variable puts more accent on the source of identification. ${ }^{11}$ The results presented here focus on the share of primary school graduates among males. Using instead the share of primary school graduates among males and females combined leads to almost identical results.

Table 5 presents OLS estimates for equation 7, where the dependent variable is the average wage and the average of the residual wage (after controlling for individual education and age). The first panel does not include district fixed effects, while the second one does. As expected, results obtained from specifications that do not control for individual education are bigger. They lump together the "social" and the "private" returns. We should, therefore, focus on the coefficients of average education in the wage residual equation. The difference between the first and the second panel illustrates the remark we made in the previous section: the OLS estimates are much bigger than the corresponding fixed effects estimates, which suggests that they are very strongly upward biased: educational attainments are higher in regions where wages are higher, but this is as likely to come from a relationship running from income to education as from the opposite relationship. ${ }^{12}$ The OLS results are all positive and significant, while the

\footnotetext{
${ }^{10}$ It means that when we change year, there is both a cohort effect and an age effect. I have run all the specifications in a sample which maintains a constant cohort composition, and the results were very similar.

${ }^{11}$ In addition, the first stage is stronger for this variable, which minimizes the problems that can arise from using weakly correlated instruments. One would expect the results with the 20-60 average to be a scaled up version of the results obtained with the 20-40 average.

${ }^{12}$ There are many reasons, besides those emphasized here, which would lead OLS coefficient to be biased upwards. First, there may be a wealth effect in education: Glewwe and Jacoby (2000) find an important wealth effect in Vietnam. Second, with economic growth, expected returns to education improve, and this may lead to a
} 
OLS results with fixed effect are positive, but significant only in the specification that has the proportion of primary school graduates among those aged 20 to 60 as the dependent variable. These point estimates suggest small positive effects: an increase of 10 percentage points in the share of primary school graduates among those aged 20 to 60 is associated with an increase of $0.8 \%$ in the wages, after controlling for individual education. These coefficients are less than one tenth of those estimated by Moretti (1999) for the impact of the share of college graduates in the US.

Table 6 presents the instrumental variables results. The results are presented for the entire sample, and for a sample that excludes the years 1998 and 1999, since the crisis hit different regions differently. The first line of each panel presents the results on wages. In the full sample, the estimates become more negative when the crisis years are taken, while the estimates in rural affect the estimates in the rural areas. The second line presents the results using the residual wages as the dependent variable. None of the estimates is significant. The estimates obtained using the residual wage or the actual wages as the dependent variable are very similar, which is reassuring: Since the INPRES instruments affects only average education, and not individual education, controlling for individual education should not affect the estimate, which is what we find here. The estimates using the residual wage are somewhat more precise. They suggest that an increase of 10 percentage points in the share of primary school graduates among the 20 to 60 year old led to a decrease of $3.8 \%$ in wages in the full sample, and to a decrease of $9.9 \%$ in the sample of rural areas. Without using the last two years of data, the coefficients are respectively $-4.4 \%$ and $-9 \%$. The negative coefficients are significant (at the $10 \%$ level) in the rural sample only.

If we focus on the share of primary school graduates among the 20 to 40 year old (for which the first stage has more power), the story is the same: an increase of 10 percentage points in the share of primary school graduates leads to a decrease of $2.9 \%$ in the wage of the old in the higher demand for education (see Foster and Rosenzweig (1996) for micro-economic evidence of the Indian green revolution, and Bils and Klenow (1998) for a re-interpretation of the cross-country evidence along these lines. 
full sample, and to a decrease of $6.3 \%$ in the rural sample.

\subsection{Skill premium}

The third line in panel A and B of table 5 presents the results of estimating by OLS (with and without district dummies) an equation similar to equation 7 , but where the dependent variable is the difference between the average wages of educated and uneducated workers. Without district dummies, the estimate is negative, large (around -0.45), and significant. With district dummies, the estimates are negative, but much smaller (around -0.09) and insignificant. OLS seems again to be biased upwards (in absolute value).

The third line in panels $\mathrm{A}$ and $\mathrm{B}$ of table 6 presents the instrumental variables estimates of the same equation. The IV estimates of the effect of the share of primary school graduates on the primary education premium are either negative or positive, and always insignificant. The education premium does not seem to have been affected by the increase in the number of primary school graduates. It suggests that, in at least one sector of the economy, educated and uneducated workers are close substitutes.

\subsection{Formal labor force participation}

The fourth line in panels A and B of table 6 presents the instrumental variables results for formal labor force participation (corresponding OLS results are presented in table 5). The dependent variable is the fraction of people who work for a wage. The 2SLS estimates suggest that there is a strong positive effect of the fraction of primary school graduates on the probability that someone works for a wage. In the rural and urban sample combined, a $10 \%$ increase in the proportion of primary school graduates among the 20 to 40 year old leads to a $4.5 \%$ increase in the probability of working for a wage. A $10 \%$ increase in the proportion of primary school graduates among the 20 to 60 year old leads to a $6.6 \%$ to $7.5 \%$ increase. The coefficients are significant in all of the specifications, and are very similar across specifications. 


\subsection{Sample selection}

There are two possible sources of sample selection. First, there might be selective migration. Second, since the program affected the proportion of people for whom we observe wages, the probability of selection in the sample is affected by the instruments. In particular, one can imagine a situation where the program pushed the "marginal" self-employed into the formal labor force, and these marginal employees receive a lower wage. Moreover, new entrants into the labor force have less experience, which should lower their wages.

Figure 2 (and columns 3 and 6 in table 4) suggest that the average education of individuals born before 1962 in the sample was not affected by the program: along this observable dimension, the sample remains comparable over time. Likewise, when I regress in the education level of the individuals born before 1962 and who earn a wage on the interactions between the program intensity and the survey year dummies, there is no distinct pattern in this regression (the $\mathrm{F}$ statistic of the interactions is 1.03), which indicates that, along observable characteristics at least, the composition of the formal labor force did not change as a result of the program.

However, there may have been selective migration along unobserved dimensions (if low productivity old people are attracted by the program regions for example, or if high productivity old people leave the region), which will cause a downward bias in the effect of the program on wages. The SAKERNAS data does not indicate whether an individual is a migrant, and we do not have any income measure for individuals who are not working for a wage. We thus need other sources of information to shed light on this issue.

First, the SUPAS data set (the 1995 intercensal survey of Indonesia which we described earlier) has the individual's region of birth as well as his region of residence. To investigate whether there are differences in productivity between migrants and non-migrants that are correlated with the INPRES program, I form for each district the difference between the logarithm of the hourly wage of the migrants and that of the non-migrants (among those born before 1962 currently residing in the district). Column 1 of table 7 presents a regression of this variable on 
the number of INPRES schools built per capita in the region. The coefficient of the number of schools is actually positive (but insignificant), which suggest that there is no downward sample selection bias. In column 2, I construct the difference between the wage of those who migrated out of their region of birth and those who staid. This difference is unrelated to the level of the program. There is thus no evidence that selective migration was likely to bias the results downward.

Second, we use the SUSENAS data (a nationally representative survey of about 50,000 households, which has an income and a consumption supplements once every 5 years). I used the incomes modules from the SUSENAS from 1987 and 1993 and computed the ratio of the household income of self employed to household of wage earners the income of wage earners. The ratio is very stable between 1987 and 1993: self-employed earn 17.85\% less than employed in 1987 , and $18.5 \%$ less in 1993 . I then regressed the difference in the log of this ratio (table 7, column (3)) on the level of the program, and found no relationship (the coefficient of the INPRES program is 0.0021 , with an absolute t statistic of 0.130 ).

On balance, it therefore appears that the relative wage loss of the old generation in regions where the program increased the supply of primary school graduates cannot be attributed to a composition effect.

We can summarize the results from this section as follows. An increase in the share of the educated workers leads to:

- A decline in the wage of older workers, whose level of education did not change. The point estimate is large (as large as the skill premium itself, or even larger in rural areas), although it is significant only in some specifications.

- No change in the skill premium among older workers.

- An increase in the share of the labor force employed in the formal sector, among the old. The point estimates are large (a 10\% increase in the share of educated workers leads to an increase of at least $4 \%$ in the share of old workers employed in the formal sector) and 
significant.

- No change in the difference between formal and informal sector earnings.

In the next section, we build a model which can explain these effects, and serve as a framework to interpret their magnitude.

\section{Model and interpretation}

What do these results tell us about the the response of the economy to an increase in the education of the labor force? In this section, I use a simple two-sector model as a framework to interpret these effects and their magnitude. In the first subsection, I set up the model and study the effect of education on wage and the allocation of labor across sectors, taking capital as given. In the second subsection, I use this model to compare its prediction to the data. I specify two polar cases for the accumulation of capital. In the first case, there is no adjustment cost. In the second case, physical capital accumulation does not adjust at all to the modification in the rate of human capital accumulation. In this simple model, both assumptions have the same implication for formal labor force participation, but very different implications for wage rates.

Below, I provide some justification for the specific assumptions of the model.

The fact that the skill premium was not affected suggests that, at least in one sector, educated and uneducated workers are very strong substitutes. Since in the formal sector, workers are combined, while they are self employed in the informal sector (we can think about this sector as small scale agriculture), we will take as a starting point that educated and uneducated workers are perfect substitutes in the informal sector. Suppose that the informal sector combines land and human capital, and the formal sector combines physical and human capital. The informal sector is characterized by a downward sloping demand for effective units of labor, even in the long run (because land is a fixed factor). In the formal sector, the slope of the labor demand depends on how capital adjusts to changes in the composition of the labor force. If capital does not adjust to an increase in effective labor supply, labor demand will be downward sloping. It 
would be flat if this increase led to an offsetting increase in the supply of capital, or even slope up if there were technological externalities, or if faster capital accumulation more than offset human capital accumulation (as in Acemoglu (1996)).

Consider a simple competitive model, where wages are equalized in the formal and informal sector (for a given level of skill). Figure 5 illustrates the effect of the increase in educated workers induced by the INPRES reform on uneducated old workers. The total number of old uneducated workers and their allocation between the formal and the informal sector are depicted on the $\mathrm{X}$ axis. The left $\mathrm{Y}$ axis presents the wage in the formal sector, and the right $\mathrm{Y}$ axis presents the wage in the informal sector. The increase in the number of educated workers leads to a shift in the labor supply expressed in efficiency unit, which is akin to a shift to the right of the labor demand expressed in number of bodies in the informal sector, and a shift to the left in the formal sector. If the labor demand in the formal sector is downward slopping, the effect on wages is unambiguously negative. The effect of an increase in the number of educated workers on the allocation of labor between formal and informal sector depends on the ratio of the elasticity of substitution between capital and labor in the formal sector and that between land and labor in the informal sector. The observation that the increase in the proportion of educated worker led to a shift from the informal to the formal sector indicates that the elasticity of substitution between labor and capital is bigger than the elasticity of substitution between labor and land. We will capture this with the simplifying assumption that the informal sector uses a Leontieff technology.

\section{$5.1 \quad$ Model}

This section builds a specific model along the lines described above. We start by describing the allocation of labor and the determination of wages, taking capital as given. In the second subsection, we will compare the predictions of this model to the data, using two polar cases for the adjustment of capital to the increase of the share of educated workers: no adjustment cost, or no adjustment whatsoever. 
There is a mass 1 of workers in the economy, out of which a fraction $S$ are educated. There are two sectors, an informal (small scale agriculture) and a formal sector (industry).

Suppose that the informal sector is characterized by a Leontieff production function in terms of efficiency units:

$$
Y_{I}=\operatorname{Min}\left(T, H_{I}\right),
$$

where $H_{I}$ is the number of efficiency units employed in the informal sector, and $T$ is the (normalized) amount of available land.

In addition, assume that educated and uneducated workers are perfect substitutes in the informal sector:

$$
H_{I}=U_{I}+h E_{I},
$$

where $h$ is the relative efficiency of educated workers. Land is distributed optimally between educated and uneducated workers, and both earn their marginal productivity, so that the ratio of the educated to the uneducated wage is $h$.

The production function in the formal sector is Cobb-Douglas in human and physical capital, with constant returns to scale:

$$
Y_{F}=A_{F} K^{\alpha} H_{F}^{1-\alpha}
$$

Human capital is a Cobb-Douglas aggregate of educated and uneducated workers:

$$
H_{F}=E_{F}^{\beta} U_{F}^{1-\beta}
$$

Wages in the formal sector are given by the marginal productivity of each factor:

$$
w_{E F}=(1-\alpha) A_{F} K^{\alpha} H_{F}^{-\alpha} \beta E_{F}^{\beta-1} U_{F}^{1-\beta},
$$

and

$$
w_{U F}=(1-\alpha) A_{F} K^{\alpha} H_{F}^{-\alpha}(1-\beta) E_{F}^{\beta} U_{F}^{-\beta} .
$$

In equilibrium, the ratio $\frac{w_{E F}}{w_{U F}}$ must be equal to $h$. Therefore the ratio of uneducated to educated labor in the formal sector must satisfy the relationship: 


$$
\frac{U_{F}}{E_{F}}=h \frac{1-\beta}{\beta}
$$

Together with the relationships $E_{F}+E_{I}=S, U_{F}+U_{I}=1-S$ and $h E_{I}+U_{I}=T$, this determines the employment of each category of workers in each sector:

$$
\begin{aligned}
E_{F} & =\frac{\beta}{h}[1+S(h-1)-T] \\
E_{I} & =\frac{\beta}{h}\left[T-1-S(h-1)+\frac{h}{\beta} S\right] \\
U_{F} & =(1-\beta)[1+S(h-1)-T] \\
U_{I} & =T-\beta\left[T-1-S(h-1)+\frac{h}{\beta} S\right]
\end{aligned}
$$

Production in the formal sector can be expressed as a function of $E_{F}$ :

$$
Y_{F}=A_{F}\left(\left(h \frac{1-\beta}{\beta}\right)^{1-\beta}\right)^{1-\alpha} K^{\alpha} E_{F}^{1-\alpha}
$$

The wage of an educated worker is therefore given by:

$$
\begin{gathered}
\ln \left(w_{E}\right)=C+\alpha \ln (K)-\alpha \ln \left(E_{F}\right), \\
\ln \left(w_{E}\right)=C^{\prime}+\alpha \ln (K)-\alpha \ln (1+S(h-1)-T),
\end{gathered}
$$

where $C$ and $C^{\prime}$ are functions of $\alpha, \beta, A_{F}$ and $h$.

The same equations (with different $C$ and $C^{\prime}$ ) describe the wage of an uneducated worker.

\subsection{Calibration}

\subsubsection{Effect of education on formal employment}

The ratio of educated to uneducated workers in the formal sector, divided by the skill premium, should be constant, according to our model, should and allow us to calculate $\beta$. In fact, the ratio of the number of uneducated workers to the number of educated workers is decreasing over time (table 1, column 5), while the skill premium is stable (table 1, column 6 ). The value 
of $\beta$ obtained from equation 10 is therefore increasing. This may reflect factors not taken into account, such as the adoption of more skill-complementary technologies. The average value of $\beta$ is 0.62 .

Equations 11 and 13 indicate how the employment of educated and uneducated workers in the formal sector responds to a change in $S$. Suppose that all the newly educated workers are "born" into the informal sector, and that young and old workers shift from the informal to the formal sector to restore the correct proportion between $E_{F}$ and $U_{F}$. When $S$ increases by $1 \%$, the probability that an educated worker born before 1962 will be employed in the formal sector

increases by $\frac{\beta}{h} \frac{(h-1)}{S_{o}}$, and the probability that an uneducated worker born before 1962 will be

employed in the informal sector increases by $(1-\beta) \frac{(h-1)}{1-S_{o}}$, where $S_{o}$ is the share of educated workers among the old.

Values of the parameters $\beta, h$ and $S_{o}$ are shown in tables 1 and 3. The average value of $h-1$ (the skill premium) is close to 0.40 . The average value of $S_{o}$ is around 0.65 . The model would therefore predict that an increase in $S$ of one percentage point would make the educated and uneducated born before 1962, respectively, 0.29 percent and 0.41 percent more likely to work in the formal sector.

The coefficients we have estimated suggest that an increase in $S$ of one percentage point leads to an increase in the probability of working for a wage of 0.43 (in the combined sample) and 0.71 (in the rural sample) for the educated workers. For the uneducated workers, the estimated effects are respectively 0.51 (in the combined sample) and 0.31 (in the rural sample). Therefore, the model does a reasonable job in predicting the shift from the informal to the formal sector for the uneducated, and under-predicts the shift of the educated from the formal to the informal sector, especially in the rural sample.

\subsubsection{Effect of an increase in average education on wage rates}

The effect of the increase in average education on the wages (at a given level of human capital) depends on the extent to which physical capital adjusts to the increase in human capital. We 
contrast the implications of two polar cases. In the first case, capital adjusts costlessly to the modification induced by INPRES: we first consider the situation where each district is a closed economy with local accumulation, and then a situation where capital is freely mobile across regions. Both models deliver the results that wage growth across regions should not be differentially affected. In the second case, there is no adjustment at all of the physical capital stock in response to the INPRES program, over the period we consider.

- Costless capital stock adjustment, local capital accumulation

To study the consequences of the INPRES model in the case of costless adjustment, we need to specify how human capital and physical capital are accumulated. Following Barro and Sala-I-Martin (1995) (chapter 5), consider a one-sector endogenous growth model, with human and physical capital. Output is divided between consumption and investment in the two forms of capital.

$$
Y=A_{F} K^{\alpha} H_{F}^{(1-\alpha)}+T=C+I_{K}+I_{H},
$$

where $I_{K}$ and $I_{H}$ are the gross investment in physical and human capital, respectively.

The changes in the capital stocks are given by:

$$
\dot{K}=I_{K}-\delta K
$$

and

$$
\dot{H}_{F}=\eta I_{H}(t-L)-\delta H_{F}
$$

There are two differences from the set up in Barro and Sala-I-Martin (1995). First, there is a lag of duration $L$ between investment in human capital and the date at which it will become active: this reflects the fact that children who go to school today will enter the job market only after a lag. Second, $\eta$ represents the ratio at which each unit of investment is transformed into a unit of human capital. ${ }^{13}$ Note that $H$ could not accumulate indefinitely if the only way to increase $H$ were to increase the proportion of primary school graduates. We should think of $H$

\footnotetext{
${ }^{13}$ In the dual economy model, $\eta$ reflects both the cost of producing educated workers, and the rate at which the educated workers are participating in the formal labor market.
} 
as a Cobb-Douglas aggregate of all levels of education: we model the beginning of the process of development, where only two levels of education have been achieved.

The solution to this problem is obtained by setting up the Hamiltonian expression for the household choice between consumption and investment in human or physical capital, taking first order conditions with respect to $C, I_{H}, I_{K}, K$ and $H_{F}$. The steady state growth rate is equal to:

$$
\gamma=\frac{1}{\theta}\left[A_{F} \alpha\left(\frac{K}{H_{F}}\right)^{\alpha-1}-\delta-\rho\right]
$$

The steady state value of $\frac{K}{H_{F}}$ is pinned down by the condition of equality between net returns to investment in physical and human capital. It is the solution to the following implicit equation:

$$
\eta e^{L\left[\delta-\alpha A_{F}\left(\frac{K}{H_{F}}\right)^{\alpha-1}\right]}\left(\frac{K}{H_{F}}\right)^{\alpha}=\frac{\alpha}{1-\alpha},
$$

Denote $k^{*}$ the value of $\frac{K}{H_{F}}$ given by this equation. The steady state growth rate is given by:

$$
\gamma^{*}=\frac{1}{\theta}\left[A_{F} \alpha k^{*(\alpha-1)}-\delta-\rho\right]
$$

We can model the effect of the INPRES program as an increase in $\eta$, the rate at which investment is transformed into human capital accumulation: each new school makes it cheaper to accumulate human capital. Suppose that the INPRES program will last long enough that we can think about it as a permanent program (a permanent increase in $\eta$ ). ${ }^{14}$ In the new steady state, the ratio $k^{*}$ will be lower than in the old steady state, to maintain the equality between net returns to investment in human capital and physical capital (see equation 17). The program should therefore cause a drop in the levels of wages (keeping constant human capital). After the transition, consumption, human capital and physical capital will grow at the same new steady state rate (given by equation 18). In the new steady state, growth in human capital will be exactly compensated by growth in physical capital, and wage growth will therefore be

\footnotetext{
${ }^{14}$ For our purpose, it would not be easy to distinguish it from a temporary program, since the the rate of capital accumulation was more rapid in the regions that received more schools for the entire period we consider.
} 
unaffected by growth in human capital. To see this, differentiate equation 15 with respect to time, and note that $\frac{\dot{K}}{K}=\frac{\dot{H}_{F}}{H_{F}}$, so that the two terms cancel.

The transition to the new steady state involves indeed a decline of $\frac{K}{H_{F}}$, and therefore a decline in wages. In this model, however, the adjustment in the ratio $\frac{K}{H_{F}}$ should have taken place right after the program was initiated, and well before the rate of growth of $H$ actually starts to accelerate. To see this, imagine that the economy was initially at a steady state, and consider the household decision the first day the schools are built: human capital investment has suddenly become cheaper, while physical capital investment has the same price and the same returns as before (since the human capital available today keeps growing at the old steady state growth rate). Net returns to investing in human capital are therefore higher, all the investment takes the form of human capital, and the ratio $\frac{K}{H_{F}}$ declines rapidly until it is low enough that investing in physical capital become profitable again. Simulations of the transitional dynamics of this model show that the ratio $\frac{K}{H_{F}}$ reaches its steady state value very fast after the program is initiated (in one year if there if household are allowed to transform physical capital into human capital, and in less than 3 years otherwise).${ }^{15}$ After reaching its new steady state value, the ratio $\frac{K}{H_{F}}$ stay almost constant. ${ }^{16}$

This very fast adjustment rate may seem unrealistic, but this is because the assumption we have made (costless capital adjustment) is not realistic either, even though it underlies, implicitly or explicitly, the effort to identify a human capital externality (in which case the share of educated worker could have a positive effect on wages. The important point is to note that in this model, the share of educated workers should not affect wages from 1986 to 1999. A

\footnotetext{
${ }^{15}$ For example, if $\gamma_{1}$ was initially $3.5 \%$ a year, assuming a value of 0.05 for $\delta, \frac{K}{H_{F}}$ would have declined by $8 \%$ every year. With reasonable parameters values for $\alpha, \delta, \rho$, and $\theta(\alpha=0.3, \delta=0.05, \rho=0.02, \theta=3)$, and assuming that the effect of each school on the rate of growth of $S$ we observe in the data is the steady state effect (i.e. each school causes an increase of $0.5 \%$ in the growth rate), $\frac{K}{H_{F}}$ should fall by about $10 \%$ for each school built (per 1000 children), which would have been achieved in 1.25 years. On average, 2 schools were built, so in 2.5 years, $\frac{K}{H_{F}}$ should have fallen enough in the average region to reach the new steady state value.

${ }^{16}$ In the simulations, there are small oscillations around the steady state values, and they are progressively dampening.
} 
full adjustment model similar to this one underlies, The data does not seem to support this full adjustment model for Indonesia, however: during the entire period, wages grow more slowly in regions were human capital grows faster (see figure 4B).

- Costless capital stock adjustment, national capital accumulation and capital is freely mobile across regions.

If capital is freely mobile across regions and there are no adjustment costs, the capital stock simply adjusts to the increase in human capital to equalize the returns to physical capital across regions. This determines the physical capital/human capital ratio $k$, which in turns determines the wage: thus (absent positive externalities), the evolution of wages should not be different in regions that received more schools (the level of wages may of course be related to the program). Once again, the data does not seem to support this model.

There were more than 10 years between the start of the program and the entry into the labor force of the generations that were exposed to it. Thus, even if capital accumulates with a gap (there is "time to build"), the conclusions of such a model would be unchanged.

Thus, it seems that, to account for the pattern present of the data, it is necessary to introduce frictions in the adjustment of the capital stock. We consider this an extreme case of frictions.

- No adjustment of the capital stock in response to the increase in education

The other extreme is a case where there is absolutely no response of physical capital accumulation to the increase in the stock of educated workers. The stock of capital is thus evolving exogenously. In this case, if the INPRES program is a valid instrument (that is, if it is not correlated with the exogenous rate of capital accumulation), the stock of capital enters the error term in equation 15 and is uncorrelated with the level of the program. The best way to check whether our model fits the facts is to use $\ln \left(E_{F}\right)$ or $\ln (1+S(h-1)-T)$ as the dependent variable instead of $S .{ }^{17}$ Figure 6 shows that these variables are also influenced by the program. The

\footnotetext{
${ }^{17} \ln \left(E_{F}\right)$ is the proportion of the labor force that is educated and works in the formal sector. $\ln (1+S(h-1)-T)$ is calculated using the district and year-specific skill premium. $T$ is calculated using its definition: $T=H_{I}=$ $U_{I}+h * E_{I}$.
} 
first stage coefficients for these variables look similar to each other, which is reassuring. ${ }^{18}$ The figure also looks similar to figure 2. In table 8, I present the results of estimating equation 15 , using the same strategy outlined for estimating the effect of $S$ on wages. In practice, I estimate equation 7 , with $\ln \left(E_{F}\right)$ or $\ln (1+S(h-1)-T)$ as the endogenous regressor of interest.

The coefficients of a subset of the specifications estimated in table 6 are presented in table 8 . For $\ln \left(E_{F}\right)$ (columns (1) and (2)), the pattern is similar to what we found for $S$ : the coefficients are negative, but insignificant. The point estimate is -0.07 in the urban sample, and -0.22 in the rural sample. The latter estimate of -0.22 is close to -0.3 , the conventional guess for $\alpha$.

The results using $\ln (1+S(h-1)-T)$ as the independent variable are more clear cut. The point estimates are similar in the combined sample and in the rural sample. The estimates range between -0.34 and -0.40 , and are all significant at the $10 \%$ level of confidence (after correcting the standard errors for auto-correlation over time within regions). These estimates (especially those obtained in the combined sample) are higher than what I obtained using $\ln \left(E_{F}\right)$ (they should in principle be the same). They are very close to (and not significantly different from) -0.3 . These estimates are fairly precise and their order of magnitude is reasonable. They reinforce the confidence in the ability of the model to describe the response of the economy to the education expansion.

Note that the model predicts that the effect of the program on wages should be the same in the formal and in the informal sector. As we already noted, the SAKERNAS does not have data on income for those who do not work for a wage. However, the regression in column 3 of table 7 , which we commented on in section 4.5, suggests that the ratio of the income of the wage earners to that of non-wage earners was not affected by the program: the difference between the value of this ratio in 1993 and in 1987 is not correlated at all with the intensity of the program.

This set of estimates therefore suggests that the accumulation of physical capital happens essentially independently from the accumulation of human capital. Even 25 years after the

\footnotetext{
${ }^{18} \mathrm{I}$ estimate the same specification as in equation 1 , but I use $\ln E_{F}$ and $\ln (1+S(h-1)-T)$, respectively, as the dependent variables. Full results are presented in table A1.
} 
program was initiated, physical capital does not seem to have been accumulated to employ the new efficiency units of labor created by the program. This conclusion seems consistent with other evidence on the pattern of industrialization in Indonesia during the period. After 1984, the Indonesian Government cut all previously existing tax incentives to geographical dispersion and small businesses Hill (1996). Miguel et al. (2001) show that there was divergence in industrialization across regions between 1985 and 1995: industrialization was faster during this period in regions where its level was higher in 1985. Change in the rate of industrialization seem uncorrelated with school construction (not only INPRES schools, but all primary and junior high schools) in the previous decade, as well as with other infrastructure variables (roads or electricity).

\section{Conclusion}

This paper argued that the INPRES program, a large school construction program undertaken by the Indonesian government in the 1970's, constitutes a good case study to empirically examine the impact of average primary schooling on the wages of older cohorts. This program modified the enrollment rates of the young generations, thus inducing a long-lasting change in the rate of human capital accumulation in the regions it affected most. The impact of this shock on the supply of educated workers can be studied on an "old" generation that did not directly benefit from it. It provides a natural solution to the identification problems inherent to any attempt to identify the effect of the average of a regressor while trying at the same time to control for it.

The instrumental variables estimates presented in this paper suggest that the effect of average education on individual wages (keeping the skill level constant) is negative: in places where average educational attainments grew faster because of the program, wages grew more slowly. This does not seem to be due to sample selection bias due to migration or increases in labor force participation. This is in sharp contrast to the OLS estimates, which are strongly positive, and to the fixed effect estimates, which are closer to zero but still positive. Such a strong bias in the OLS estimates suggests that the cross-country relationship between output per capita and 
education is likely to be affected by the same upward bias. The effects of average education on the participation in the formal labor market is, however, positive.

Both sets of estimates are shown to be consistent with a simple dual-economy model, where the number of efficiency units that can be productively employed in the informal sector is limited by the availability of a fixed factor (land, for example). The increase in the productivity of the labor force is entirely absorbed by the formal sector, which explains the increase in participation. Wages decrease to the extent that physical capital does not fully adjust to the increase in human capital. I contrast three versions of this model. In a closed economy endogenous growth version with costless adjustment of the capital stock, the faster increase in human capital after 1986 should be matched with a corresponding increase in the stock of physical capital, and wages should be unaffected. In an open economy model where capital moves freely, the capital-labor ratio adjusts to maintain equal returns to physical capital across regions, and the program should have no effect on wages. If capital accumulation is unresponsive to the increase in human capital, the model makes a prediction of what the coefficient on the human capital variable should be.

The extent to which wages fall in response to the increase in human capital available in the formal sector suggests that there was little or no reaction of the physical capital to the increase in educational opportunities in the regions where INPRES built more schools. The estimates I obtain are reasonable if this is the right model of the world.

What is absent in this paper (and left for future work) is an explanation of why the capital stock did not adjust. The program was publicly announced, and the increase in the stock of primary school graduates occurred gradually over 10 years after the program started. It is a puzzle that 25 years after the program was initiated, the labor demand looks like a "short run" labor demand curve. Future work (and, probably, more data) is needed to determine to what extent this is due to "myopic" behavior of investors, who fail to recognize the increase in the education level of the labor force, to very large adjustment costs of the capital stock, to a financing constraint, or to a combination of the three.

The results in this paper are important because, contrary to what is often assumed (on the 
basis of the experience of South-East Asian countries), acceleration in the rate of accumulation of human capital is not necessarily accompanied by economic growth. Several countries (in Africa, in particular) had very rapid expansion in education, but dismal economic growth (Kremer and Thomson (1998)). It is important to understand why this can be the case.

Models of credit constraints (Banerjee and Newman (1993), Galor and Zeira (1993), Aghion and Bolton (1997)) could be combined with models of costly adjustment of technology to study the effects of education on economic growth given the actual constraints faced by developing economies. The work of Caballero and Hammour $(1998,2000)$ comes closest to doing this. Their model combines costly adjustment with credit constraints but does not model growth. It cannot therefore be directly applied to the question of what happens when the growth rate of human capital increases. Once built, such a model could then be compared to actual evolutions, in exercises similar to Blanchard (1997) analysis of the "medium run".

\section{References}

Acemoglu, Daron (1996) 'A microfoundation for social increasing returns in human cpital accumulation.' Quarterly Journal of Economics 111(3), 779-804

Acemoglu, Daron, and Joshua Angrist (1999) 'How large are the social returns to education? Evidence from compulsory schooling laws.' Mimeo, MIT

Aghion, Philippe, and Patrick Bolton (1997) 'A trickle-down theory of growth and development with debt overhang.' Review of Economic Studies 64(2), 151-72

Atkinson, A.B., and A. Brandolini (1999) "Promise and pitfalls in the use of "secondary" datasets: Income inequality in OECD countries.' Mimeo, Nuffield College, Oxford

Banerjee, Abhijit, and Andrew Newman (1993) 'Occupational choice and the process of development.' Journal of Political Economy 101(2), 274-298 
Banerjee, Abhijit, and Esther Duflo (2000) 'Inequality and growth: What can the data say?' Working Paper 7793, National Bureau of Economic Research, July

Barro, Robert, and Xavier Sala-I-Martin (1995) Economic Growth (Mc Graw Hill)

Bertrand, Marianne Esther Duflo, and Sendhil Mullainathan (2001) 'How much should we trust differences in differences estimates.' Mimeo, MIT

Bils, Mark, and Peter Klenow (1998) 'Does schooling cause growth or the other way around?' Working Paper 6393, National Bureau of Economic Research

Blanchard, Olivier (1997) 'The medium run.' Brookings Papers on Economic Activity 2, 89-158

Blanchard, Olivier, and Justin Wolfers (1999) 'The role of shocks and institutions in the rise of european unemployment: The aggregate evidence.' Working Paper 7282, National Bureau of Economic Research

Bound, John, Gabor Kzedi, and Sarah Turner (2000) 'Trade in university training: Cross state variation in the production and use of college educated labor.' MIMEO, University of Michigan

Caballero, Ricardo, and Mohamad Hammour (1998) 'The macroeconomics of specificity.' Journal of Political Economy 106(4), 724-767

(2000) 'Creative destruction and development: Institutions, crises, and restructuring.' Working Paper 7849, National Bureau of Economic Research, August

Card, David, and Thomas Lemieux (2001) 'Can falling supply explain the rising return to college for younger men? A cohort-based analysis.' Quarterly Journal of Economics 116(2), 705746

Duflo, Esther (2000) 'Schooling and labor market consequences of school construction in Indonesia: Evidence from an unusual policy experiment.' Working Paper 7860, National Bureau of Economic Research, August 
_ (2001) 'Schooling and labor market consequences of school construction in Indonesia: Evidence from an unusual policy experiment.' American Economic Review 91(4), 795-813

Foster, Andrew D., and Mark R. Rosenzweig (1996) 'Technical change and human-capital returns and investments: Evidence from the green revolution.' American Economic Review $86(4), 931-953$

Frankenberg, Elizabeth, Duncan Thomas, and Kathleen Beegle (1999) 'The real costs of Indonesia's economic crisis: Preliminary findings from the Indonesia family life surveys.' Working Paper 99-04, RAND Labor and Population Program

Galor, Oded, and Joseph Zeira (1993) 'Income distribution and macroeconomics.' Review of Macroeconomic Studies 60, 35-52

Glewwe, Paul, and Hanan Jacoby (2000) 'Economic growth and the demand for education: Is there a wealth effect?' MIMEO, World Bank

Harris, J., and M. Todaro (1970) 'Migration, unemployment and development: A two-sector analysis.' American Economic Review 40, 126-142

Heckman, James J., Lance Lochner, and Christopher Taber (1998) 'General equilibrium treatment effects: A study of tuition policy.' Working Paper 6426, National Bureau of Economic Research

Hill, Hal (1996) The Indonesian Economy Since 1966: Southeast Asia's Emerging Giant (Cambridge: Cambridge University Press)

Katz, Lawrence F., and Kevin M. Murphy (1992) 'Changes in relative wages, 1963-1987: Supply and demand factors.' Quarterly Journal of Economics 107(1), 35-78

Kremer, Michael, and James Thomson (1998) 'Why isn't convergence instantaneous? young workers, old workers, and gradual adjustment.' Journal of Economic Growth 3, 5-28

Krueger, Alan, and Mikael Lindahl (1999) 'Education for growth: Why and for whom?' Mimeo 
Lucas, Robert (1988) 'On the mechanics of economic development.' Journal of Monetary Economics $22,3-42$

Miguel, Edward, Paul Gertler, and David Levine (2001) 'Did industrialization destroy social capital in Indonesia.' Mimeo, U.C. Berkeley

Moretti, Enrico (1999) 'Estimating the social return to education: Evidence from repeated cross-sectional and longitudinal data.' Working Paper 22, UC Berkeley

Solow, Robert M. (2000) 'Toward a macroeconomics of the medium run.' Journal of Economic Perspectives 14(1), 151-158

Welch, Finis (1979) 'Effects of cohort size on earnings: The baby boom babies' financial bust.' Journal of Political Economy 87(5), S65-S97. part 2 
Table 1: Descriptive statistics

\begin{tabular}{|c|c|c|c|c|c|c|c|}
\hline & \multicolumn{2}{|c|}{ Fraction born after 1962} & \multicolumn{2}{|c|}{ Percentage of primary school graduates } & \multirow{2}{*}{$\begin{array}{c}\text { ratio of } \\
\text { uneducated/educated } \\
\text { in formal sector }(20-60)\end{array}$} & \multirow{2}{*}{$\begin{array}{c}\text { Skill } \\
\text { premium }\end{array}$} & \multirow{2}{*}{$\begin{array}{c}\text { Implied } \\
\text { beta }\end{array}$} \\
\hline & $20-40$ & $20-60$ & $20-40$ & $20-60$ & & & \\
\hline & $(1)$ & $(2)$ & (3) & $(4)$ & $(5)$ & $(6)$ & $(7)$ \\
\hline 1986 & 0.22 & 0.15 & 0.69 & 0.61 & 0.36 & 0.40 & 0.53 \\
\hline 1987 & 0.25 & 0.16 & 0.71 & 0.63 & 0.33 & 0.41 & 0.55 \\
\hline 1988 & 0.32 & 0.21 & 0.73 & 0.64 & 0.29 & 0.33 & 0.53 \\
\hline 1989 & 0.36 & 0.23 & 0.74 & 0.65 & 0.29 & 0.39 & 0.57 \\
\hline 1990 & 0.42 & 0.28 & 0.76 & 0.68 & 0.29 & 0.35 & 0.55 \\
\hline 1991 & 0.46 & 0.31 & 0.79 & 0.71 & 0.22 & 0.31 & 0.58 \\
\hline 1992 & 0.49 & 0.32 & 0.79 & 0.71 & 0.23 & 0.35 & 0.60 \\
\hline 1993 & 0.55 & 0.36 & 0.8 & 0.72 & 0.19 & 0.41 & 0.68 \\
\hline 1994 & 0.58 & 0.38 & 0.81 & 0.74 & 0.21 & 0.36 & 0.63 \\
\hline 1995 & 0.62 & 0.42 & 0.79 & 0.72 & 0.21 & 0.43 & 0.67 \\
\hline 1996 & 0.67 & 0.44 & 0.85 & 0.79 & 0.23 & 0.37 & 0.62 \\
\hline 1997 & 0.71 & 0.46 & 0.84 & 0.78 & 0.17 & 0.41 & 0.71 \\
\hline 1998 & 0.77 & 0.51 & 0.87 & 0.81 & 0.17 & 0.38 & 0.69 \\
\hline 1999 & 0.82 & 0.53 & 0.88 & 0.82 & 0.13 & 0.35 & 0.73 \\
\hline
\end{tabular}

Notes: 1. Average wage is average of the log of monthly wage

2-Means are weighted by the number of observations ineach district-year cell

3. See text for the definition of Beta 
Table 2: First stage regressions

Effect of the program on the proportion of individuals completing primary school or more. Coefficients of interactions of the intensity of the program and survey year dummies.

\begin{tabular}{|c|c|c|c|c|c|c|}
\hline \multirow{3}{*}{ Sample: } & \multicolumn{3}{|c|}{ Sample: Urban and rural areas } & \multicolumn{3}{|c|}{ Sample: rural areas only } \\
\hline & $20-40$ & $20-60$ & $\begin{array}{c}\text { Born } \\
\text { before } 1962\end{array}$ & $20-40$ & $20-60$ & $\begin{array}{c}\text { Born } \\
\text { before } 1962\end{array}$ \\
\hline & $(1)$ & $(2)$ & (3) & (4) & $(5)$ & $(6)$ \\
\hline 1986 & omitted & omitted & omitted & omitted & omitted & omitted \\
\hline 1987 & $\begin{array}{r}0.0028 \\
(.008)\end{array}$ & $\begin{array}{r}-0.0004 \\
(.0075)\end{array}$ & $\begin{array}{r}-0.0026 \\
(.0077)\end{array}$ & $\begin{array}{l}0.0009 \\
(.0099)\end{array}$ & $\begin{array}{r}-0.0015 \\
(.009)\end{array}$ & $\begin{array}{r}-0.0023 \\
(.0091)\end{array}$ \\
\hline 1988 & $\begin{array}{l}0.0015 \\
(.0064)\end{array}$ & $\begin{array}{c}-0.0028 \\
(.0058)\end{array}$ & $\begin{array}{r}-0.0050 \\
(.0059)\end{array}$ & $\begin{array}{r}-0.0032 \\
(.0078)\end{array}$ & $\begin{array}{r}-0.0079 \\
(.0069)\end{array}$ & $\begin{array}{r}-0.0088 \\
(.0069)\end{array}$ \\
\hline 1989 & $\begin{array}{l}0.0014 \\
(.0053)\end{array}$ & $\begin{array}{r}-0.0012 \\
(.0047)\end{array}$ & $\begin{array}{r}-0.0048 \\
(.005)\end{array}$ & $\begin{array}{r}-0.0010 \\
(.0066)\end{array}$ & $\begin{array}{r}-0.0043 \\
(.0056)\end{array}$ & $\begin{array}{r}-0.0068 \\
(.0061)\end{array}$ \\
\hline 1990 & $\begin{array}{l}0.0027 \\
(.0061)\end{array}$ & $\begin{array}{r}-0.0042 \\
(.0056)\end{array}$ & $\begin{array}{r}-0.0106 \\
(.0059)\end{array}$ & $\begin{array}{r}-0.0002 \\
(.0072)\end{array}$ & $\begin{array}{r}-0.0071 \\
(.0065)\end{array}$ & $\begin{array}{r}-0.0126 \\
(.007)\end{array}$ \\
\hline 1991 & $\begin{array}{l}0.0151 \\
(.0058)\end{array}$ & $\begin{array}{l}0.0074 \\
(.0055)\end{array}$ & $\begin{array}{c}-0.0002 \\
(.0055)\end{array}$ & $\begin{array}{l}0.0110 \\
(.0067)\end{array}$ & $\begin{array}{l}0.0032 \\
(.0062)\end{array}$ & $\begin{array}{r}-0.0034 \\
(.0065)\end{array}$ \\
\hline 1992 & $\begin{array}{l}0.0124 \\
(.0065)\end{array}$ & $\begin{array}{l}0.0006 \\
(.0061)\end{array}$ & $\begin{array}{r}-0.0074 \\
(.0061)\end{array}$ & $\begin{array}{l}0.0082 \\
(.0076)\end{array}$ & $\begin{array}{l}-0.0058 \\
(.0068)\end{array}$ & $\begin{array}{r}-0.0126 \\
(.007)\end{array}$ \\
\hline 1993 & $\begin{array}{l}0.0205 \\
(.0065)\end{array}$ & $\begin{array}{l}0.0088 \\
(.0062)\end{array}$ & $\begin{array}{r}-0.0017 \\
(.0059)\end{array}$ & $\begin{array}{l}0.0143 \\
(.0072)\end{array}$ & $\begin{array}{l}0.0012 \\
(.0067)\end{array}$ & $\begin{array}{r}-0.0082 \\
(.0067)\end{array}$ \\
\hline 1994 & $\begin{array}{l}0.0195 \\
(.0068)\end{array}$ & $\begin{array}{l}0.0076 \\
(.0068)\end{array}$ & $\begin{array}{r}-0.0044 \\
(.0069)\end{array}$ & $\begin{array}{l}0.0145 \\
(.0074)\end{array}$ & $\begin{array}{l}0.0005 \\
(.0072)\end{array}$ & $\begin{array}{r}-0.0103 \\
(.0078)\end{array}$ \\
\hline 1995 & $\begin{array}{l}0.0202 \\
(.0064)\end{array}$ & $\begin{array}{l}0.0074 \\
(.0063)\end{array}$ & $\begin{array}{r}-0.0064 \\
(.0061)\end{array}$ & $\begin{array}{l}0.0161 \\
(.0072)\end{array}$ & $\begin{array}{l}0.0003 \\
(.0068)\end{array}$ & $\begin{array}{r}-0.0127 \\
(.007)\end{array}$ \\
\hline 1996 & $\begin{array}{l}0.0260 \\
(.0064)\end{array}$ & $\begin{array}{l}0.0112 \\
(.0066)\end{array}$ & $\begin{array}{r}-0.0027 \\
(.0069)\end{array}$ & $\begin{array}{r}0.0207 \\
(.007)\end{array}$ & $\begin{array}{l}0.0016 \\
(.0066)\end{array}$ & $\begin{array}{r}-0.0122 \\
(.0075)\end{array}$ \\
\hline 1997 & $\begin{array}{l}0.0252 \\
(.0071)\end{array}$ & $\begin{array}{l}0.0149 \\
(.0072)\end{array}$ & $\begin{array}{l}0.0039 \\
(.0076)\end{array}$ & $\begin{array}{l}0.0190 \\
(.0077)\end{array}$ & $\begin{array}{l}0.0070 \\
(.0076)\end{array}$ & $\begin{array}{r}-0.0010 \\
(.0086)\end{array}$ \\
\hline 1998 & $\begin{array}{l}0.0340 \\
(.0077)\end{array}$ & $\begin{array}{l}0.0190 \\
(.0074)\end{array}$ & $\begin{array}{l}0.0044 \\
(.0072)\end{array}$ & $\begin{array}{l}0.0300 \\
(.0073)\end{array}$ & $\begin{array}{l}0.0110 \\
(.0066)\end{array}$ & $\begin{array}{r}-0.0040 \\
(.0076)\end{array}$ \\
\hline 1999 & $\begin{array}{l}0.0290 \\
(.0082)\end{array}$ & $\begin{array}{l}0.0154 \\
(.0082)\end{array}$ & $\begin{array}{l}0.0045 \\
(.0083)\end{array}$ & $\begin{array}{l}0.0253 \\
(.0078)\end{array}$ & $\begin{array}{l}0.0076 \\
(.0073)\end{array}$ & $\begin{array}{r}-0.0029 \\
(.0086)\end{array}$ \\
\hline $\begin{array}{l}\text { Number of } \\
\text { cells }\end{array}$ & 3826 & 3826 & 3826 & 3140 & 3140 & 3140 \\
\hline F. statistic & 7.23 & 3.40 & 1.29 & 5.02 & 1.68 & 0.95 \\
\hline
\end{tabular}

Notes:

1. The program intensity is the number of INPRES schools built between 1974 and 1978, divided by the number of children in 1971.

2. Survey year dummies, region dummies, interactions between survey year dummies and the enrollment rate in 1971, and interactions between suvey year dummies and the number of children are included in the regressions.

3. Regression run using kabupaten-year averages, weighted by the number of observations in each kabupaten-year cell.

4. The F statistic is for the hypothesis that the set of interactions is jointly insignificant.

5. The standard errors are corrected for auto-correlation within kabupaten. 
Table 3: Descriptive Statistics

Sample: individuals aged less than 60 and born before 1962

\begin{tabular}{cccccc}
\hline \hline \multirow{2}{*}{ Survey year } & \multicolumn{5}{c}{ Individuals born before 1962, aged less than 60 } \\
\cline { 2 - 7 } & $\begin{array}{c}\text { \% primary school } \\
\text { graduates }\end{array}$ & $\begin{array}{c}\text { \% working } \\
\text { for wage }\end{array}$ & $\begin{array}{c}\text { average } \\
\text { wage }\end{array}$ & $\begin{array}{c}\text { S.D. of } \\
\text { wage }\end{array}$ & $\begin{array}{c}\text { skill } \\
\text { premium }\end{array}$ \\
\cline { 2 - 7 }$(1)$ & \multicolumn{2}{c}{$(2)$} & $(3)$ & $(4)$ & $(5)$ \\
\hline & & & & & \\
1986 & 0.59 & 0.31 & 6.56 & 0.71 & 0.44 \\
1987 & 0.60 & 0.32 & 6.58 & 0.66 & 0.48 \\
1988 & 0.60 & 0.31 & 6.55 & 0.65 & 0.40 \\
1989 & 0.61 & 0.33 & 6.61 & 0.66 & 0.46 \\
1990 & 0.62 & 0.33 & 6.66 & 0.67 & 0.46 \\
1991 & 0.65 & 0.34 & 6.70 & 0.66 & 0.44 \\
1992 & 0.64 & 0.33 & 6.77 & 0.67 & 0.47 \\
1993 & 0.65 & 0.34 & 6.81 & 0.73 & 0.51 \\
1994 & 0.66 & 0.36 & 6.88 & 0.71 & 0.47 \\
1995 & 0.64 & 0.36 & 6.93 & 0.72 & 0.57 \\
1996 & 0.71 & 0.35 & 6.98 & 0.68 & 0.50 \\
1997 & 0.69 & 0.36 & 7.08 & 0.72 & 0.54 \\
1998 & 0.72 & 0.33 & 6.82 & 0.69 & 0.54 \\
1999 & 0.74 & 0.33 & 6.86 & 0.70 & 0.57 \\
\hline
\end{tabular}


Table 4: Reduced form regressions

Effect of the program on wages, residual wages, and formal employment among individuals born before 1962. Coefficients of interactions of the intensity of the program and survey year dummies

\begin{tabular}{|c|c|c|c|c|c|c|}
\hline & \multicolumn{3}{|c|}{$\begin{array}{c}\text { Sample: Urban and rural areas } \\
\text { 20-60 years old, born before } 1962\end{array}$} & \multicolumn{3}{|c|}{$\begin{array}{c}\text { Sample: Rural areas only } \\
\text { 20-60 years old, born before } 1962\end{array}$} \\
\hline & Wages & $\begin{array}{l}\text { Residual } \\
\text { wage }\end{array}$ & $\begin{array}{c}\text { Formal } \\
\text { employment }\end{array}$ & Wages & $\begin{array}{l}\text { Residual } \\
\text { wage }\end{array}$ & $\begin{array}{c}\text { Formal } \\
\text { employment }\end{array}$ \\
\hline & $(1)$ & $(2)$ & (3) & (4) & $(5)$ & (6) \\
\hline 1986 & omitted & omitted & omitted & omitted & omitted & omitted \\
\hline 1987 & $\begin{array}{l}0.0025 \\
(.0187)\end{array}$ & $\begin{array}{r}-0.0064 \\
(.014)\end{array}$ & $\begin{array}{r}-0.0087 \\
(.0056)\end{array}$ & $\begin{array}{r}0.0209 \\
(.018)\end{array}$ & $\begin{array}{l}0.0094 \\
(.0139)\end{array}$ & $\begin{array}{r}-0.0059 \\
(.0056)\end{array}$ \\
\hline 1988 & $\begin{array}{r}-0.0041 \\
(.0152)\end{array}$ & $\begin{array}{r}-0.0051 \\
(.0141)\end{array}$ & $\begin{array}{r}-0.0040 \\
(.004)\end{array}$ & $\begin{array}{l}0.0108 \\
(.0139)\end{array}$ & $\begin{array}{l}0.0103 \\
(.0136)\end{array}$ & $\begin{array}{r}-0.0047 \\
(.0042)\end{array}$ \\
\hline 1989 & $\begin{array}{l}0.0022 \\
(.0161)\end{array}$ & $\begin{array}{r}-0.0011 \\
(.0139)\end{array}$ & $\begin{array}{r}-0.0074 \\
(.0047)\end{array}$ & $\begin{array}{l}0.0155 \\
(.0159)\end{array}$ & $\begin{array}{l}0.0095 \\
(.0141)\end{array}$ & $\begin{array}{r}-0.0081 \\
(.0044)\end{array}$ \\
\hline 1990 & $\begin{array}{r}-0.0140 \\
(.0155)\end{array}$ & $\begin{array}{r}-0.0111 \\
(.0133)\end{array}$ & $\begin{array}{r}-0.0027 \\
(.0054)\end{array}$ & $\begin{array}{l}0.0047 \\
(.0165)\end{array}$ & $\begin{array}{l}0.0056 \\
(.0143)\end{array}$ & $\begin{array}{r}-0.0030 \\
(.0054)\end{array}$ \\
\hline 1991 & $\begin{array}{r}-0.0061 \\
(.0187)\end{array}$ & $\begin{array}{r}-0.0079 \\
(.0146)\end{array}$ & $\begin{array}{l}0.0035 \\
(.0051)\end{array}$ & $\begin{array}{l}0.0082 \\
(.0185)\end{array}$ & $\begin{array}{l}0.0047 \\
(.0149)\end{array}$ & $\begin{array}{l}0.0039 \\
(.0049)\end{array}$ \\
\hline 1992 & $\begin{array}{r}-0.0173 \\
(.0163)\end{array}$ & $\begin{array}{r}-0.0116 \\
(.0141)\end{array}$ & $\begin{array}{l}0.0019 \\
(.0055)\end{array}$ & $\begin{array}{r}-0.0055 \\
(.0186)\end{array}$ & $\begin{array}{l}0.0021 \\
(.0145)\end{array}$ & $\begin{array}{r}-0.0002 \\
(.0055)\end{array}$ \\
\hline 1993 & $\begin{array}{r}-0.0166 \\
(.0156)\end{array}$ & $\begin{array}{r}-0.0132 \\
(.0137)\end{array}$ & $\begin{array}{l}0.0069 \\
(.0055)\end{array}$ & $\begin{array}{r}-0.0097 \\
(.0203)\end{array}$ & $\begin{array}{r}-0.0038 \\
(.017)\end{array}$ & $\begin{array}{l}0.0074 \\
(.0054)\end{array}$ \\
\hline 1994 & $\begin{array}{r}-0.0222 \\
(.0165)\end{array}$ & $\begin{array}{r}-0.0189 \\
(.0136)\end{array}$ & $\begin{array}{r}0.0103 \\
(.007)\end{array}$ & $\begin{array}{r}-0.0149 \\
(.0224)\end{array}$ & $\begin{array}{r}-0.0170 \\
(.0175)\end{array}$ & $\begin{array}{l}0.0068 \\
(.0069)\end{array}$ \\
\hline 1995 & $\begin{array}{l}0.0031 \\
(.0145)\end{array}$ & $\begin{array}{l}-0.0010 \\
(.0134)\end{array}$ & $\begin{array}{l}0.0071 \\
(.0056)\end{array}$ & $\begin{array}{l}0.0044 \\
(.0188)\end{array}$ & $\begin{array}{r}0.0079 \\
(.015)\end{array}$ & $\begin{array}{l}0.0058 \\
(.0051)\end{array}$ \\
\hline 1996 & $\begin{array}{r}-0.0190 \\
(.0176)\end{array}$ & $\begin{array}{r}-0.0173 \\
(.0143)\end{array}$ & $\begin{array}{r}-0.0035 \\
(.0071)\end{array}$ & $\begin{array}{l}-0.0158 \\
(.0251)\end{array}$ & $\begin{array}{r}-0.0116 \\
(.0178)\end{array}$ & $\begin{array}{r}-0.0051 \\
(.0062)\end{array}$ \\
\hline 1997 & $\begin{array}{l}-0.0192 \\
(.0174)\end{array}$ & $\begin{array}{l}-0.0155 \\
(.0169)\end{array}$ & $\begin{array}{l}0.0061 \\
(.0068)\end{array}$ & $\begin{array}{l}-0.0119 \\
(.0232)\end{array}$ & $\begin{array}{r}-0.0166 \\
(.0183)\end{array}$ & $\begin{array}{l}0.0042 \\
(.0066)\end{array}$ \\
\hline 1998 & $\begin{array}{r}-0.0079 \\
(.0189)\end{array}$ & $\begin{array}{r}-0.0141 \\
(.0157)\end{array}$ & $\begin{array}{l}0.0083 \\
(.0074)\end{array}$ & $\begin{array}{r}-0.0190 \\
(.0219)\end{array}$ & $\begin{array}{r}-0.0072 \\
(.0164)\end{array}$ & $\begin{array}{l}0.0105 \\
(.0072)\end{array}$ \\
\hline 1999 & $\begin{array}{r}0.0034 \\
(.019)\end{array}$ & $\begin{array}{r}-0.0104 \\
(.0159)\end{array}$ & $\begin{array}{l}0.0078 \\
(.0071)\end{array}$ & $\begin{array}{l}-0.0188 \\
(.0238)\end{array}$ & $\begin{array}{r}-0.0189 \\
(.0185)\end{array}$ & $\begin{array}{l}0.0074 \\
(.0076)\end{array}$ \\
\hline $\begin{array}{l}\text { Number of } \\
\text { cells }\end{array}$ & 3804 & 3804 & 3804 & 3119 & 3119 & 3119 \\
\hline
\end{tabular}

Notes:

1. The program intensity is the number of INPRES schools built between 1974 and 1978, divided by the number of children in 1971.

2. Survey year dummies, region dummies, interactions between survey year dummies and the enrollment rate in 1971, and interactions between suvey year dummies and the number of children are included in the regressions.

3. Regression run using kabupaten-year averages, weighted by the number of observations in each kabupaten-year cell.

4. The standard errors are corrected for auto-correlation within kabupaten. 
Table 5: OLS estimates of the impact of average education on individual wages.

Men aged 20-60 and born before 1962.

\begin{tabular}{|c|c|c|c|c|}
\hline & \multicolumn{2}{|c|}{$\begin{array}{l}\text { Independent variable: } \% \text { of primary } \\
\text { school graduates in the } 20-40 \text { sample }\end{array}$} & \multicolumn{2}{|c|}{$\begin{array}{l}\text { Independent variable: } \% \text { of primary } \\
\text { school graduates in the } 20-60 \text { sample }\end{array}$} \\
\hline & $\begin{array}{l}\text { Sample: Rural } \\
\text { and urban areas }\end{array}$ & $\begin{array}{l}\text { Sample: Rural } \\
\text { areas only }\end{array}$ & $\begin{array}{l}\text { Sample: Rural } \\
\text { and urban areas }\end{array}$ & $\begin{array}{l}\text { Sample: Rural } \\
\text { areas only }\end{array}$ \\
\hline & $(1)$ & $(2)$ & $(3)$ & $(4)$ \\
\hline \multicolumn{5}{|c|}{ PANEL A: OLS, without region fixed effects (1986-1999) } \\
\hline $\log ($ wage $)$ & $\begin{array}{r}0.852 \\
(0.035)\end{array}$ & $\begin{array}{r}0.754 \\
(0.041)\end{array}$ & $\begin{array}{r}0.881 \\
(0.030)\end{array}$ & $\begin{array}{r}0.875 \\
(0.037)\end{array}$ \\
\hline Log(wage) residual & $\begin{array}{r}0.195 \\
(0.024)\end{array}$ & $\begin{array}{r}0.226 \\
(0.028)\end{array}$ & $\begin{array}{r}0.228 \\
(0.021)\end{array}$ & $\begin{array}{r}0.312 \\
(0.027)\end{array}$ \\
\hline Skill premium & $\begin{array}{r}-0.458 \\
(0.041)\end{array}$ & $\begin{array}{r}-0.531 \\
(0.047)\end{array}$ & $\begin{array}{r}-0.423 \\
(0.038)\end{array}$ & $\begin{array}{r}-0.533 \\
(0.045)\end{array}$ \\
\hline Formal employment & $\begin{array}{r}0.431 \\
(0.016)\end{array}$ & $\begin{array}{r}0.162 \\
(0.015)\end{array}$ & $\begin{array}{r}0.459 \\
(0.015)\end{array}$ & $\begin{array}{r}0.170 \\
(0.015)\end{array}$ \\
\hline Formal employment among educated workers & $\begin{array}{r}0.095 \\
(0.015)\end{array}$ & $\begin{array}{r}-0.036 \\
(0.015)\end{array}$ & $\begin{array}{r}0.108 \\
(0.013)\end{array}$ & $\begin{array}{l}-0.035 \\
(0.015)\end{array}$ \\
\hline Formal employment among uneducated workers & $\begin{array}{r}0.035 \\
(0.011)\end{array}$ & $\begin{array}{r}0.0046 \\
(0.011)\end{array}$ & $\begin{array}{r}0.045 \\
(0.011)\end{array}$ & $\begin{array}{r}0.0088 \\
(0.011)\end{array}$ \\
\hline \multicolumn{5}{|l|}{ PANEL B: OLS, with region fixed effects (1986-1999) } \\
\hline $\log ($ wage $)$ & $\begin{array}{r}0.409 \\
(0.041)\end{array}$ & $\begin{array}{r}0.436 \\
(0.046)\end{array}$ & $\begin{array}{r}0.537 \\
(0.041)\end{array}$ & $\begin{array}{r}0.594 \\
(0.047)\end{array}$ \\
\hline Log(wage) residual & $\begin{array}{r}0.040 \\
(0.032)\end{array}$ & $\begin{array}{r}0.060 \\
(0.035)\end{array}$ & $\begin{array}{r}0.086 \\
(0.032)\end{array}$ & $\begin{array}{r}0.121 \\
(0.037)\end{array}$ \\
\hline Skill premium & $\begin{array}{r}-0.082 \\
(0.073)\end{array}$ & $\begin{array}{r}-0.092 \\
(0.080)\end{array}$ & $\begin{array}{r}-0.094 \\
(0.077)\end{array}$ & $\begin{array}{c}-0.106 \\
(0.085)\end{array}$ \\
\hline Formal employment & $\begin{array}{r}0.160 \\
(0.016)\end{array}$ & $\begin{array}{r}0.134 \\
(0.017)\end{array}$ & $\begin{array}{r}0.228 \\
(0.016)\end{array}$ & $\begin{array}{r}0.201 \\
(0.018)\end{array}$ \\
\hline Formal employment among educated workers & $\begin{array}{c}-0.0019 \\
(0.020)\end{array}$ & $\begin{array}{c}0.0079 \\
(0.022)\end{array}$ & $\begin{array}{r}0.017 \\
(0.021)\end{array}$ & $\begin{array}{r}0.031 \\
(0.022)\end{array}$ \\
\hline Formal employment among uneducated workers & $\begin{array}{r}0.012 \\
(0.016)\end{array}$ & $\begin{array}{r}0.015 \\
(0.017)\end{array}$ & $\begin{array}{r}0.031 \\
(0.018)\end{array}$ & $\begin{array}{r}0.033 \\
(0.018)\end{array}$ \\
\hline
\end{tabular}

Notes:

1. Survey year dummies, region dummies, interactions between survey year dummies and the enrollment rate in 1971, and interactions between suvey year dummies and the number of children are included in the regressions.

2. Regression run using kabupaten-year averages, weighted by the number of observations in each kabupaten-year cell. 
Table 6: 2SLS estimates of the impact of average education on individual wages.

Men aged 20-60 and born before 1962 .

\begin{tabular}{|c|c|c|c|c|}
\hline & \multicolumn{2}{|c|}{$\begin{array}{l}\text { Independent variable: \% of primary } \\
\text { school graduates in the } 20-40 \text { sample }\end{array}$} & \multicolumn{2}{|c|}{$\begin{array}{l}\text { Independent variable: } \% \text { of primary } \\
\text { school graduates in the } 20-60 \text { sample }\end{array}$} \\
\hline & $\begin{array}{l}\text { Sample: Rural } \\
\text { and urban areas }\end{array}$ & $\begin{array}{c}\text { Sample: Rural } \\
\text { areas only }\end{array}$ & $\begin{array}{l}\text { Sample: Rural } \\
\text { and urban areas }\end{array}$ & $\begin{array}{c}\text { Sample: Rural } \\
\text { areas only }\end{array}$ \\
\hline & $(1)$ & $(2)$ & $(3)$ & $(4)$ \\
\hline \multicolumn{5}{|l|}{ PANEL A: YEARS 1986-1999 } \\
\hline \multirow[t]{2}{*}{$\log ($ wage $)$} & -0.204 & -0.834 & -0.208 & -0.871 \\
\hline & $(.443)$ & $(.701)$ & $(.615)$ & $(.837)$ \\
\hline \multirow[t]{2}{*}{$\log ($ wage $)$ residual } & -0.292 & -0.633 & -0.379 & -0.994 \\
\hline & $(.355)$ & $(.431)$ & $(.512)$ & $(.556)$ \\
\hline \multirow[t]{2}{*}{ Skill premium } & -0.434 & -0.982 & -0.596 & -0.636 \\
\hline & (.916) & (1.408) & (1.197) & $(1.645)$ \\
\hline \multirow[t]{2}{*}{ Formal employment } & 0.441 & 0.454 & 0.661 & 0.745 \\
\hline & (.159) & $(.203)$ & $(.238)$ & $(.352)$ \\
\hline \multirow[t]{2}{*}{ Formal employment among educated workers } & 0.432 & 0.501 & 0.543 & 0.713 \\
\hline & $(.197)$ & $(.259)$ & $(.264)$ & $(.406)$ \\
\hline \multirow[t]{2}{*}{ Formal employment among uneducated workers } & 0.379 & 0.409 & 0.510 & 0.318 \\
\hline & $(.203)$ & $(.232)$ & $(.354)$ & $(.318)$ \\
\hline \multicolumn{5}{|l|}{ PANEL B: YEARS 1986-1997 } \\
\hline \multirow[t]{2}{*}{ Log(wage) } & -0.358 & -0.710 & -0.451 & -0.480 \\
\hline & $(.493)$ & $(.821)$ & $(.716)$ & $(.801)$ \\
\hline \multirow[t]{2}{*}{$\log ($ wage $)$ residual } & -0.330 & -0.588 & -0.437 & -0.902 \\
\hline & $(.412)$ & $(.529)$ & $(.618)$ & $(.602)$ \\
\hline \multirow[t]{2}{*}{ Skill premium } & -0.225 & -0.635 & -0.291 & 0.536 \\
\hline & $(1.033)$ & $(1.461)$ & $(1.488)$ & $(1.576)$ \\
\hline \multirow[t]{2}{*}{ Formal employment } & 0.463 & 0.442 & 0.716 & 0.694 \\
\hline & $(.183)$ & $(.233)$ & $(.282)$ & $(.379)$ \\
\hline \multirow[t]{2}{*}{ Formal employment among educated workers } & 0.428 & 0.473 & 0.530 & 0.622 \\
\hline & $(.229)$ & $(.301)$ & $(.317)$ & $(.479)$ \\
\hline \multirow[t]{2}{*}{ Formal employment among uneducated workers } & 0.478 & 0.449 & 0.624 & 0.263 \\
\hline & $(.249)$ & $(.277)$ & $(.415)$ & $(.319)$ \\
\hline
\end{tabular}

Notes:

1. Survey year dummies, region dummies, interactions between survey year dummies and the enrollment rate in 1971, and interactions between suvey year dummies and the number of children are included in the regressions.

2. Regression run using kabupaten-year averages, weighted by the number of observations in each kabupaten-year cell.

3. The instruments are interactions between survey year dummies and the program intensity

4. The standard errors are corrected for auto-correlation within kabupaten. 
Table 7: Additional evidence on sample selection

\begin{tabular}{|c|c|c|c|}
\hline & $\begin{array}{l}\text { Log(wage migrant in }) \\
\text {-log(wage stayer })\end{array}$ & $\begin{array}{l}\text { Log(wage migrant out) } \\
\text { - } \log (\text { wage stayer })\end{array}$ & $\begin{array}{l}\text { Formal sector premium } 1993 \\
\text {-Formal sector premium } 1987\end{array}$ \\
\hline & $\begin{array}{c}(1) \\
\end{array}$ & $(2)$ & $(3)$ \\
\hline \multirow[t]{2}{*}{ Program intensity } & 0.0229 & 0.011 & -0.00207 \\
\hline & $(0.0159)$ & $(0.0164)$ & $(0.0160)$ \\
\hline Number of cells & 285 & 288 & 272 \\
\hline
\end{tabular}

Note:

1. The program intensity is the number of INPRES schools built between 1974 and 1978, divided by the number of children in 1971

2. The formal sector premium is defined as : $\log$ (income of wage earner/income of non wage earners)

3. The enrollment rate and the number of children in 1971 are introduced as controls in the regressions

4. The data for columns (1) and (2) is the SUPAS 1995

5. The data for column (3) is the SAKERNAS, 1987 and 1993. 
Table 8: 2SLS estimates of the impact of human capital on wages.

$\log (\mathrm{Ef})$ and $\log (1+\mathrm{S}(\mathrm{h}-1)-\mathrm{T})$ as measures of human capital

\begin{tabular}{|c|c|c|c|c|}
\hline & \multicolumn{4}{|c|}{ Dependent variable: $\log ($ wage) for men 20- 60, born before 1962} \\
\hline & \multicolumn{2}{|c|}{$\begin{array}{c}\text { Independent variable: } \log \left(\mathrm{E}_{\mathrm{F}}\right) \\
\text { among sample aged } 20-60 \\
\end{array}$} & \multicolumn{2}{|c|}{$\begin{array}{c}\text { Independent variable: } \log (1+\mathrm{s}(\mathrm{h}-1)-\mathrm{T}) \\
\text { among sample aged } 20-60\end{array}$} \\
\hline & $\begin{array}{l}\text { Sample: Rural } \\
\text { and urban areas }\end{array}$ & $\begin{array}{c}\text { Sample: Rural } \\
\text { areas only }\end{array}$ & $\begin{array}{l}\text { Sample: Rural } \\
\text { and urban areas }\end{array}$ & $\begin{array}{l}\text { Sample: Rural } \\
\text { areas only }\end{array}$ \\
\hline & $\begin{array}{c}(1) \\
\end{array}$ & $(2)$ & $(3)$ & $(4)$ \\
\hline \multicolumn{5}{|l|}{ PANEL A: YEARS 1986-1999 } \\
\hline & $\begin{array}{r}-0.073 \\
(.164)\end{array}$ & $\begin{array}{r}-0.219 \\
(.205)\end{array}$ & $\begin{array}{r}-0.365 \\
(.217)\end{array}$ & $\begin{array}{r}-0.341 \\
(.22)\end{array}$ \\
\hline \multicolumn{5}{|l|}{ PANEL B: YEARS 1986-1997 } \\
\hline & $\begin{array}{r}-0.092 \\
(.165)\end{array}$ & $\begin{array}{r}-0.165 \\
(.208)\end{array}$ & $\begin{array}{r}-0.396 \\
(.213)\end{array}$ & $\begin{aligned}-0.360 \\
(.275)\end{aligned}$ \\
\hline
\end{tabular}

Notes:

1. Survey year dummies, region dummies, interactions between survey year dummies and the enrollment rate in 1971,

and interactions between suvey year dummies and the number of children are included in the regressions.

2. Regression run using kabupaten-year averages, weighted by the number of observations in each kabupaten-year cell.

3. The instruments are interactions between survey year dummies and program intensity

4. The standard errors are corrected for auto-correlation within kabupaten. 
Figure 1 -- COEFFICIENTS OF THE INTERACTIONS OF AGE IN 1974* PROGRAM INTENSITY IN THE REGION OF BIRTH IN THE EDUCATION EQUATION

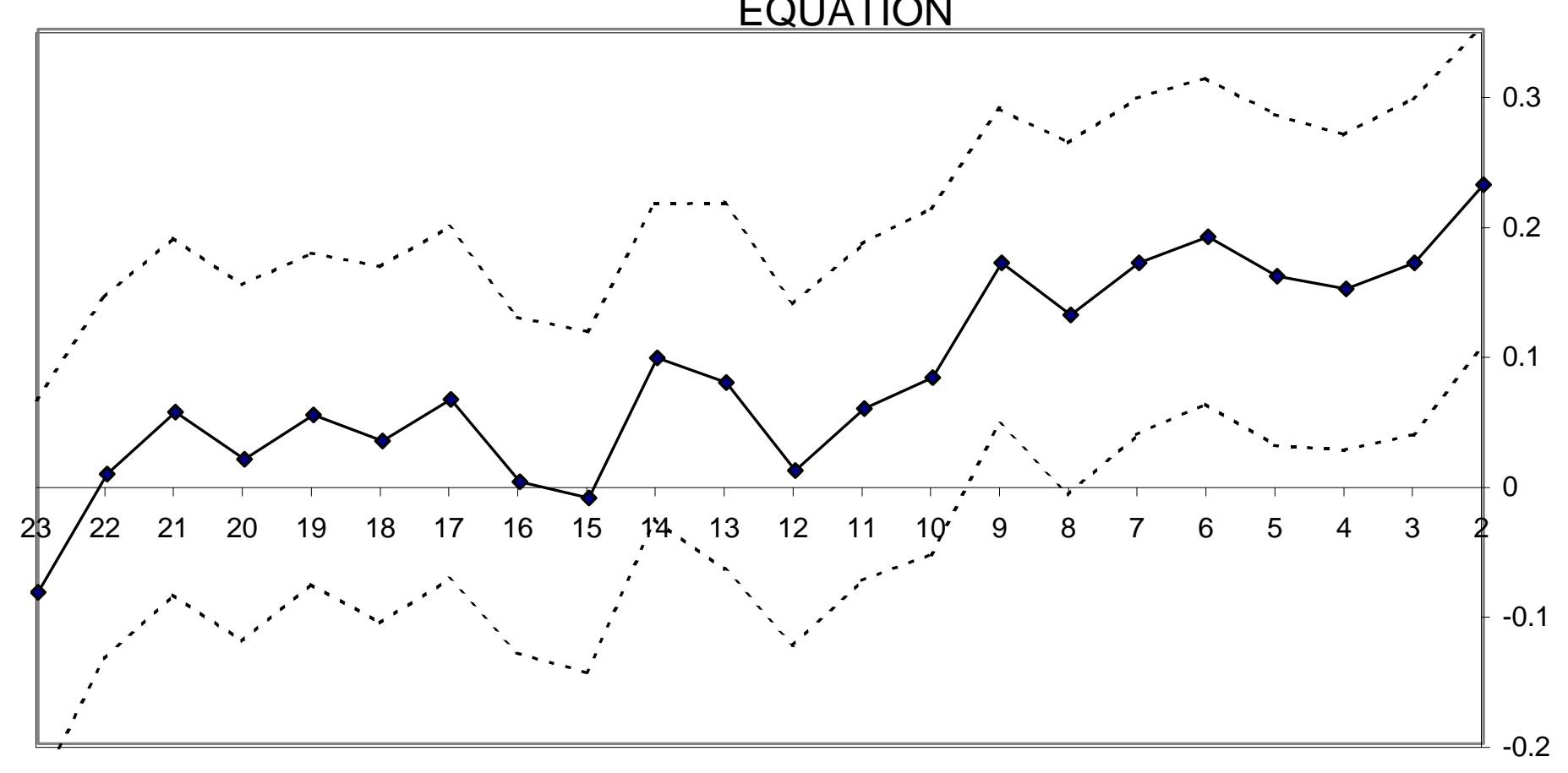

Age in 1974 
Figure 2: Coefficients of the interactions of program intensity and survey year dummies.

Dependent variable: \% of primary school graduates.

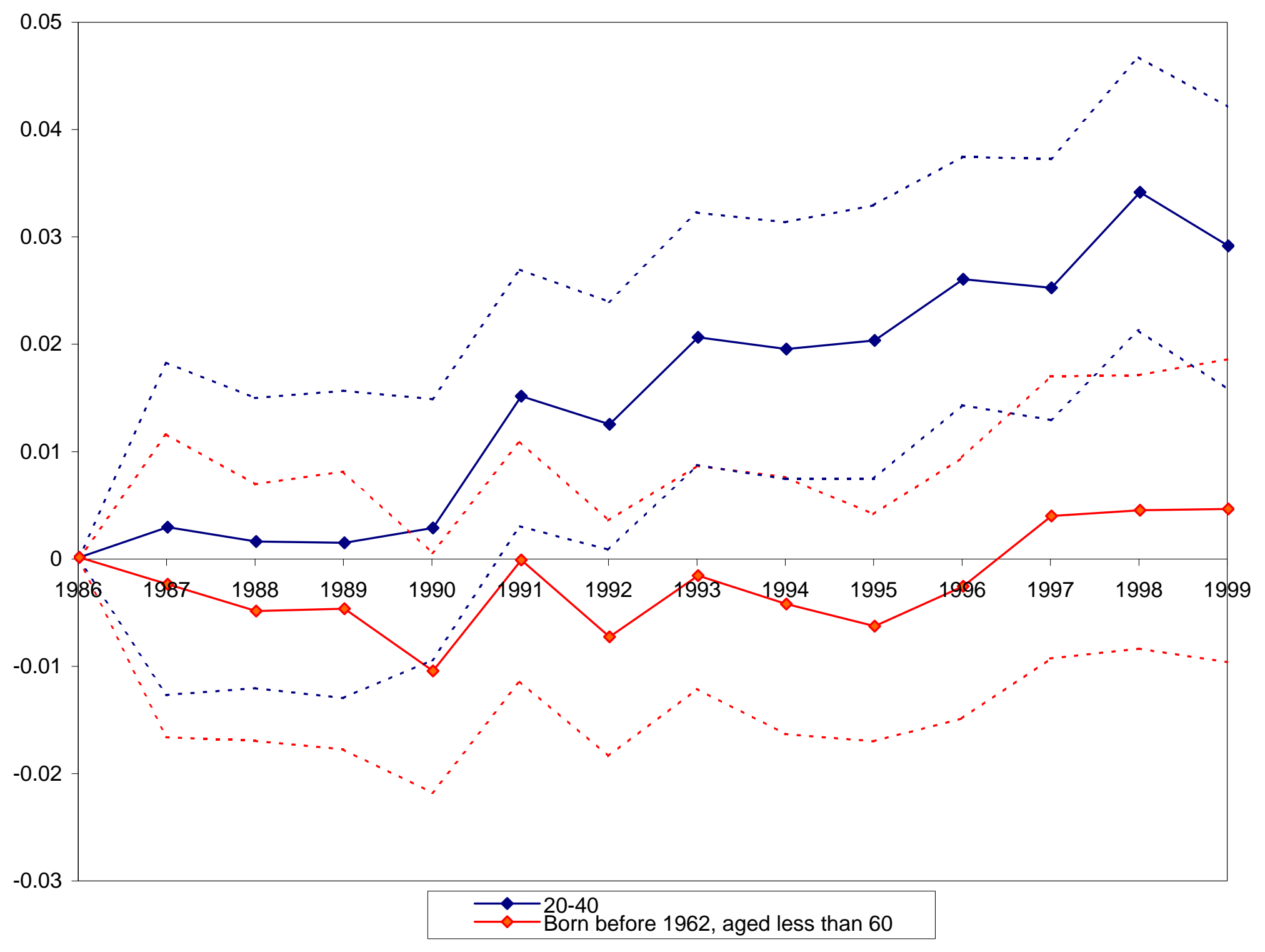


Figure 3: Actual and predicted coefficients of the interactions of program intensity and survey year dummies. Dependent variable: \% of primary school graduates.

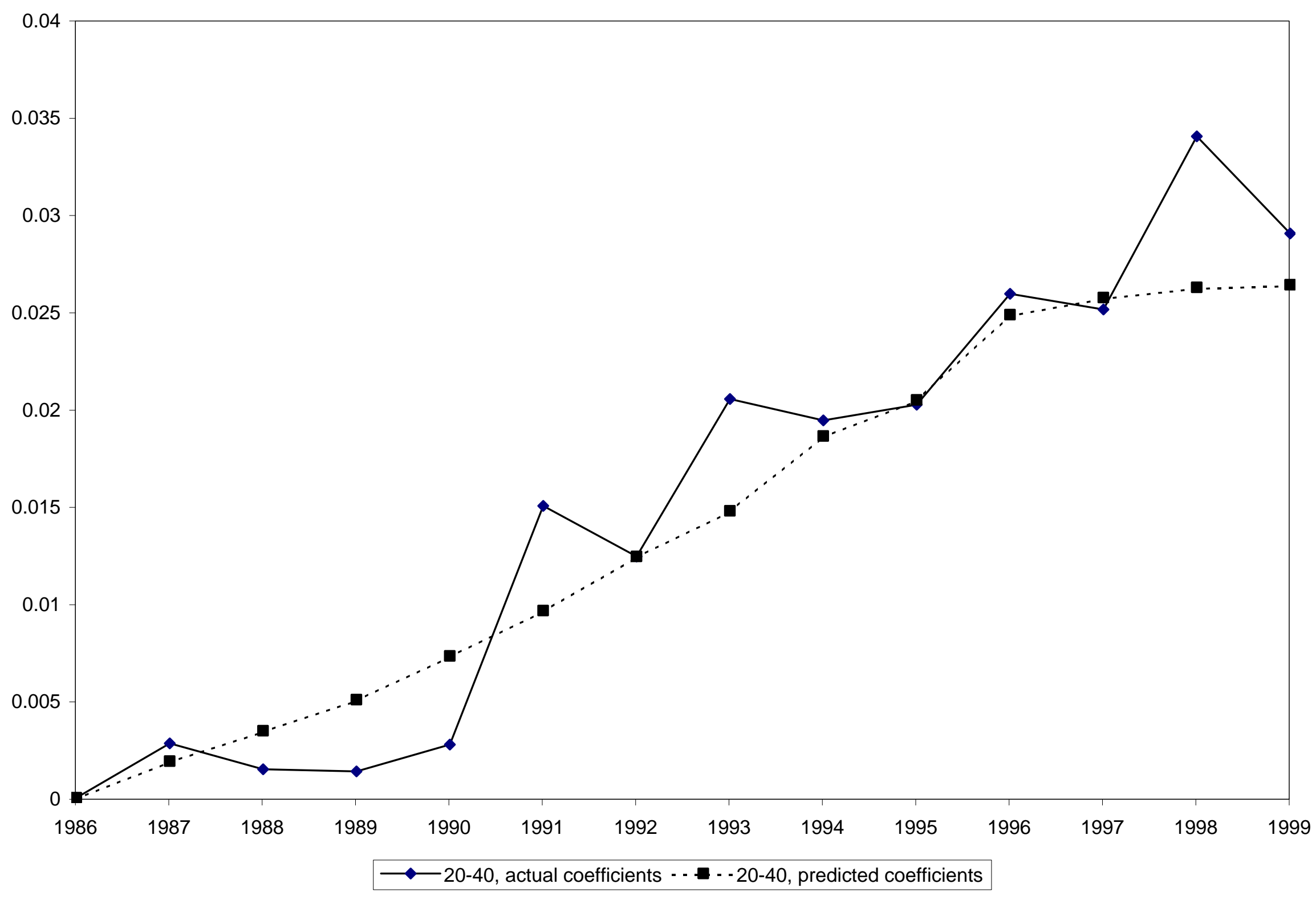


Figure 4A: Coefficients of the interactions of program intensity and survey year dummies.

Dependent variables: log(wage) and formal sector employment (individuals born before 1962 and aged less than 60) Sample: urban and rural regions.

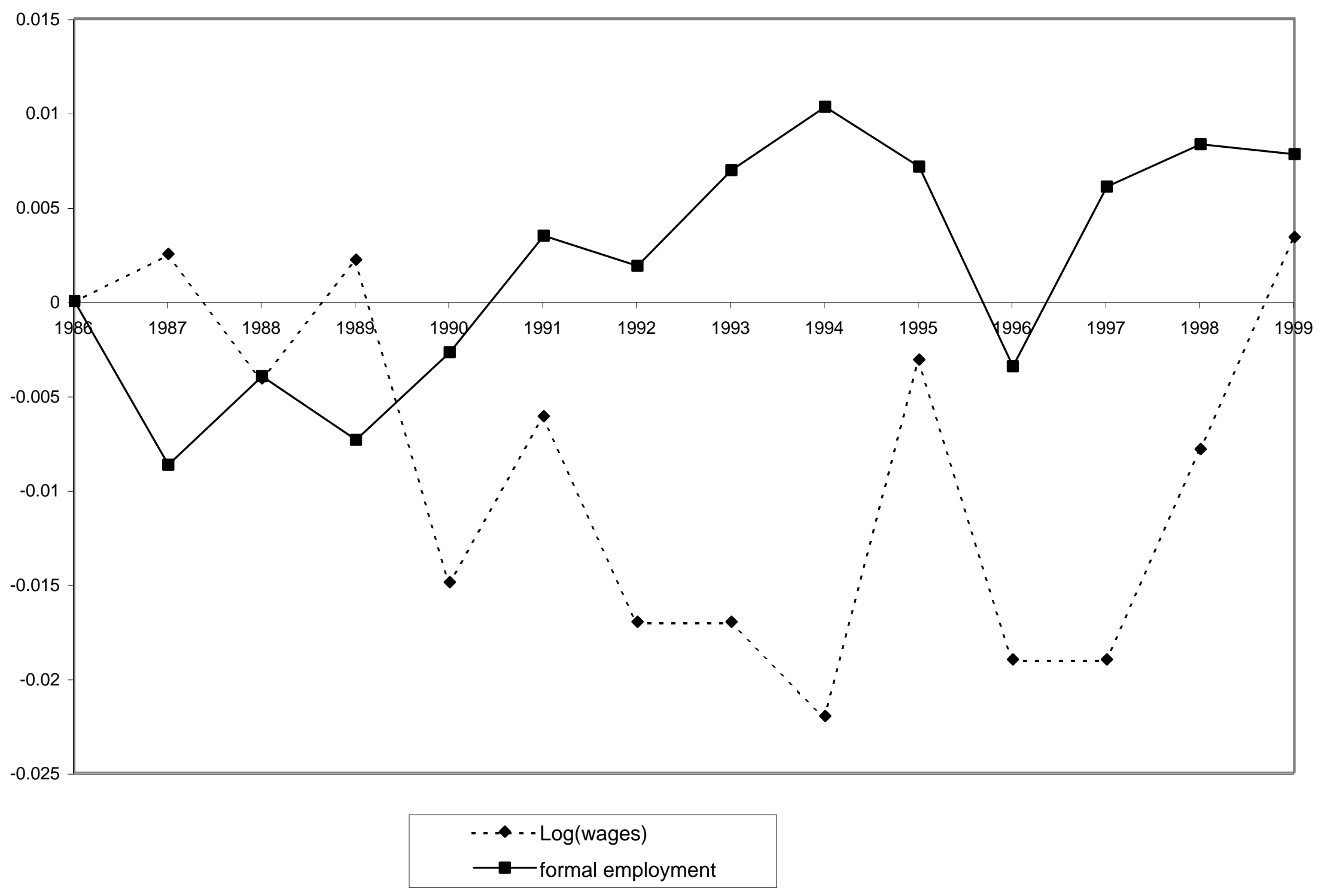


Figure 4B: Coefficients of the interactions of program intensity and survey year dummies.

Dependent variables: average log(wage) and average formal sector employment among individuals born before 1962 and aged less than 60.

Sample: rural regions.

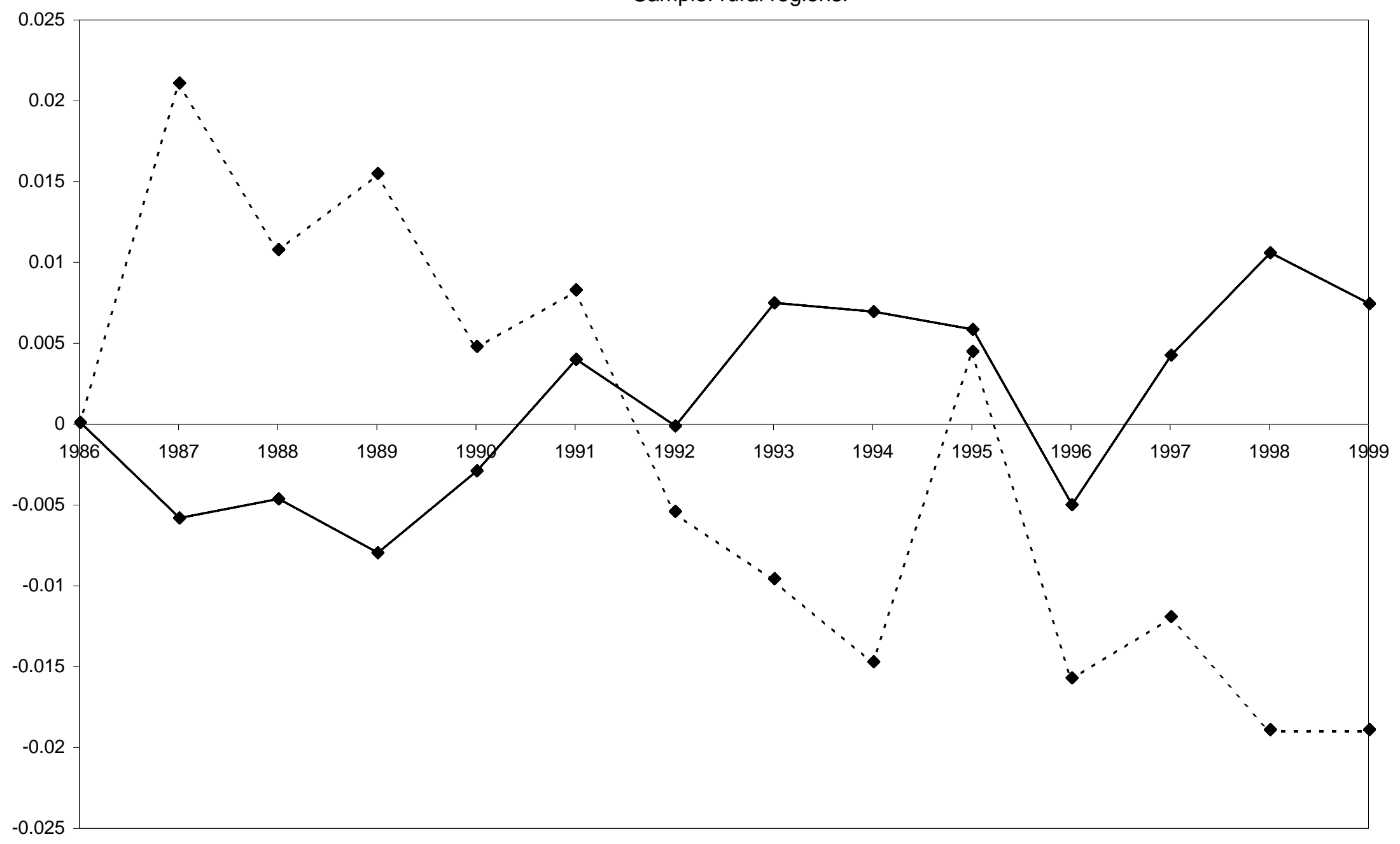


Figure 5

Effect of an Increase in the Share of Educated Workers on Wages and Formal Employment

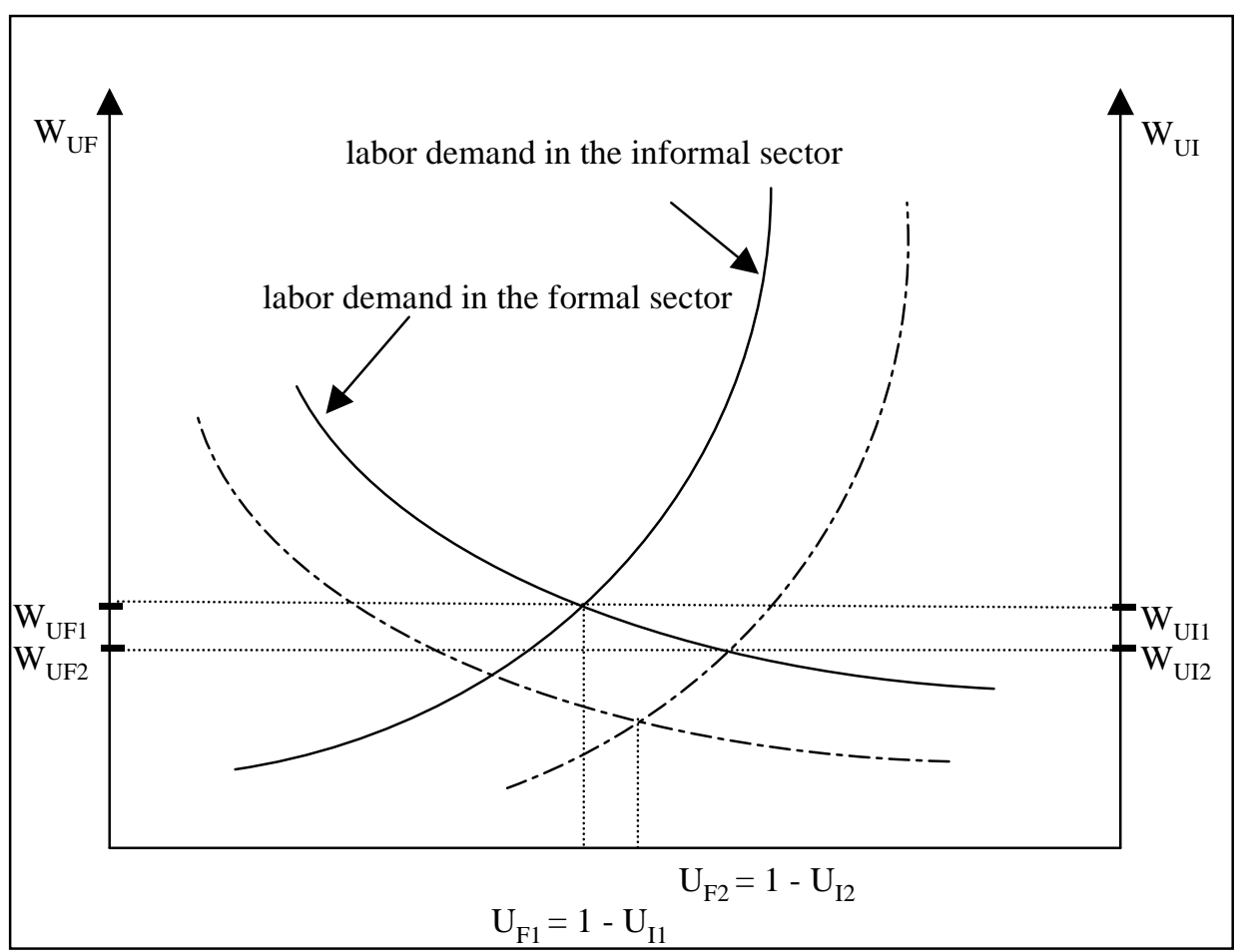


Figure 6: Coefficient of the interaction between program intensity and survey year dummies.

Dependent variable: $\log (E f)$ and $\log (1+s(h-1)-T)$

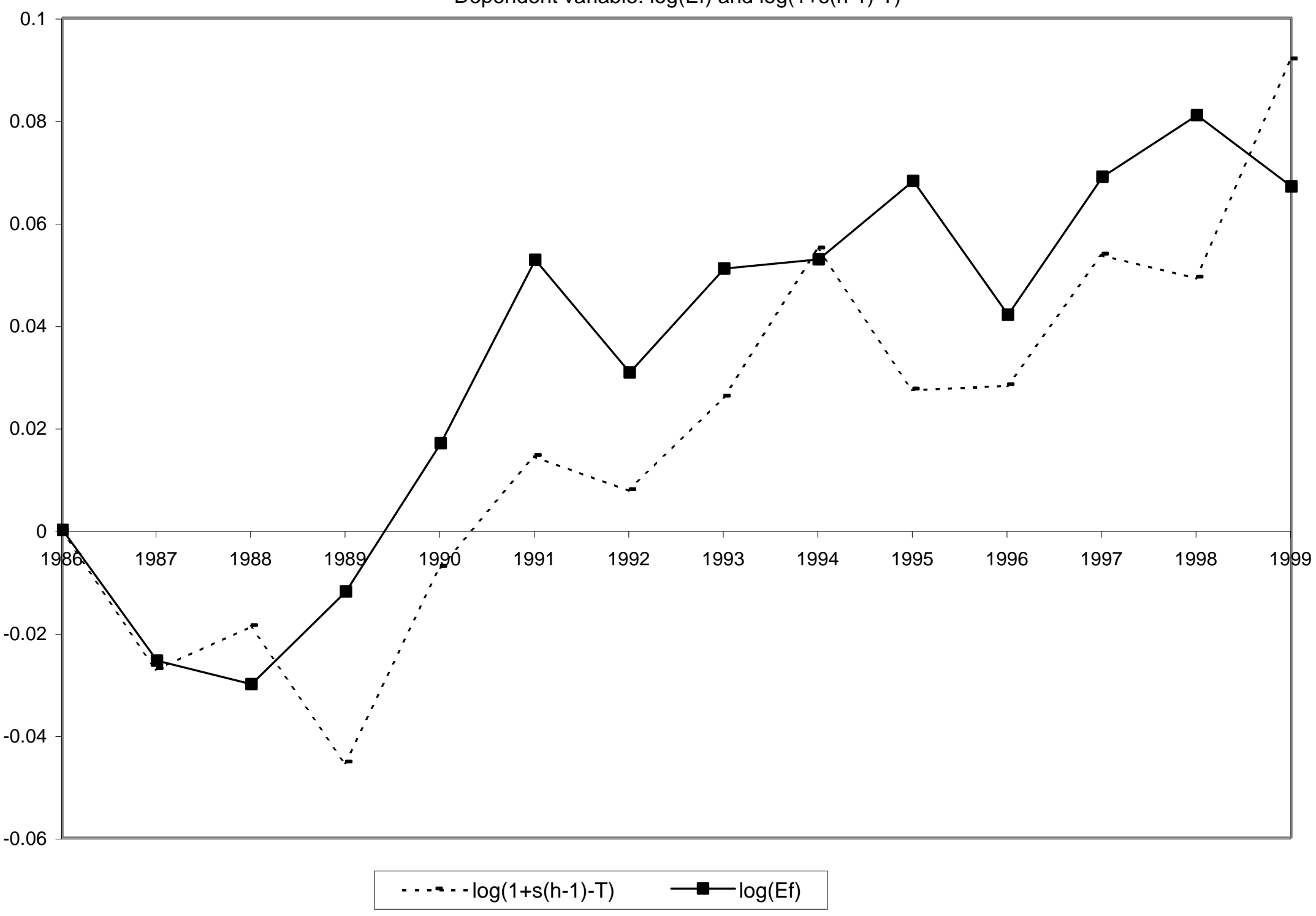


Table A1: Alternative first stage: Effect of the program on $\log (E f)$ and $\log (1+S(h-1)-T)$. Sample: Men aged 20-60

\begin{tabular}{|c|c|c|c|c|}
\hline & \multicolumn{2}{|c|}{ Independent variable: $\log (\mathrm{Ef})$} & \multicolumn{2}{|c|}{ Independent variable: $\log (1+\mathrm{s}(\mathrm{h}-1)-\mathrm{T})$} \\
\hline & $\begin{array}{l}\text { Sample: Urban } \\
\text { and rural areas } \\
\end{array}$ & $\begin{array}{c}\text { Sample: Rural } \\
\text { areas only }\end{array}$ & $\begin{array}{l}\text { Sample: Urban } \\
\text { and rural areas }\end{array}$ & $\begin{array}{c}\text { Sample: Rural } \\
\text { areas only }\end{array}$ \\
\hline & $(1)$ & $(2)$ & $(1)$ & $(2)$ \\
\hline 1986 & omitted & omitted & omitted & omitted \\
\hline 1987 & $\begin{array}{r}-0.0242 \\
(.0429)\end{array}$ & $\begin{array}{r}-0.0344 \\
(.0521)\end{array}$ & $\begin{array}{r}-0.0244 \\
(.0546)\end{array}$ & $\begin{array}{r}-0.0320 \\
(.0663)\end{array}$ \\
\hline 1988 & $\begin{array}{r}-0.0279 \\
(.022)\end{array}$ & $\begin{array}{r}-0.0502 \\
(.0259)\end{array}$ & $\begin{array}{r}-0.0131 \\
(.0304)\end{array}$ & $\begin{array}{r}-0.0248 \\
(.0361)\end{array}$ \\
\hline 1989 & $\begin{array}{l}-0.0109 \\
(.0285)\end{array}$ & $\begin{array}{l}-0.0331 \\
(.0349)\end{array}$ & $\begin{array}{r}-0.0409 \\
(.0319)\end{array}$ & $\begin{array}{r}-0.0697 \\
(.0373)\end{array}$ \\
\hline 1990 & $\begin{array}{l}0.0185 \\
(.0313)\end{array}$ & $\begin{array}{l}0.0033 \\
(.0345)\end{array}$ & $\begin{array}{r}-0.0057 \\
(.0324)\end{array}$ & $\begin{array}{r}-0.0135 \\
(.0387)\end{array}$ \\
\hline 1991 & $\begin{array}{l}0.0540 \\
(.0292)\end{array}$ & $\begin{array}{l}0.0436 \\
(.0313)\end{array}$ & $\begin{array}{r}0.0153 \\
(.03)\end{array}$ & $\begin{array}{l}0.0058 \\
(.0321)\end{array}$ \\
\hline 1992 & $\begin{array}{l}0.0320 \\
(.0307)\end{array}$ & $\begin{array}{l}0.0109 \\
(.0325)\end{array}$ & $\begin{array}{l}0.0102 \\
(.0306)\end{array}$ & $\begin{array}{r}-0.0176 \\
(.0338)\end{array}$ \\
\hline 1993 & $\begin{array}{l}0.0518 \\
(.0308)\end{array}$ & $\begin{array}{l}0.0339 \\
(.0332)\end{array}$ & $\begin{array}{l}0.0250 \\
(.0335)\end{array}$ & $\begin{array}{l}0.0008 \\
(.0373)\end{array}$ \\
\hline 1994 & $\begin{array}{l}0.0534 \\
(.0345)\end{array}$ & $\begin{array}{l}0.0238 \\
(.0392)\end{array}$ & $\begin{array}{l}0.0548 \\
(.0354)\end{array}$ & $\begin{array}{l}0.0220 \\
(.0404)\end{array}$ \\
\hline 1995 & $\begin{array}{l}0.0681 \\
(.0307)\end{array}$ & $\begin{array}{l}0.0515 \\
(.0328)\end{array}$ & $\begin{array}{l}0.0266 \\
(.0352)\end{array}$ & $\begin{array}{l}0.0198 \\
(.0363)\end{array}$ \\
\hline 1996 & $\begin{array}{l}0.0459 \\
(.0344)\end{array}$ & $\begin{array}{l}0.0231 \\
(.0343)\end{array}$ & $\begin{array}{l}0.0313 \\
(.0363)\end{array}$ & $\begin{array}{l}0.0060 \\
(.0401)\end{array}$ \\
\hline 1997 & $\begin{array}{l}0.0703 \\
(.0375)\end{array}$ & $\begin{array}{l}0.0510 \\
(.0414)\end{array}$ & $\begin{array}{l}0.0522 \\
(.0404)\end{array}$ & $\begin{array}{l}0.0327 \\
(.0477)\end{array}$ \\
\hline 1998 & $\begin{array}{l}0.0807 \\
(.0351)\end{array}$ & $\begin{array}{l}0.0708 \\
(.0371)\end{array}$ & $\begin{array}{l}0.0417 \\
(.0517)\end{array}$ & $\begin{array}{l}0.0137 \\
(.0615)\end{array}$ \\
\hline 1999 & $\begin{array}{l}0.0691 \\
(.0357)\end{array}$ & $\begin{array}{l}0.0598 \\
(.0383)\end{array}$ & $\begin{array}{l}0.0918 \\
(.0476)\end{array}$ & $\begin{array}{r}0.1131 \\
(.063)\end{array}$ \\
\hline $\begin{array}{l}\text { Number of } \\
\text { cells }\end{array}$ & 3808 & 3122 & 3336 & 2762 \\
\hline F. statistic & 3.28 & 2.49 & 1.69 & 1.30 \\
\hline
\end{tabular}

Notes:

1. The program intensity is the number of INPRES schools built between 1974 and 1978, divided by number of children in 1971.

2. Survey year dummies, region dummies, interactions between survey year dummies and the enrolln rate in 1971, and interactions between suvey year dummies and the number of children are included in the regressions.

3. Regression run using kabupaten-year averages, weighted by the number of observations in each kabupaten-year cell.

4. The F statistic is for the hypothesis that the set of interactions is jointly insignificant.

5. See text for variables definition

6. The standard errors are corrected for auto-correlation within kabupaten. 